\title{
Managers' Private Information, Investor Underreaction and Long-Run SEO Performance
}

\section{Pawel Bilinski}

Lancaster University Management School, Lancaster University, Lancaster, LA1 4YX, UK

Email:p.bilinski@lancaster.ac.uk

\section{Norman Strong}

Manchester Business School, University of Manchester, Booth Street East, Manchester, M156PB, UK

Email:norman.strong@mbs.ac.uk

\begin{abstract}
For a sample of 2,879 SEOs by US stocks from 1970 to 2004, this paper decomposes an average three-year post-issue buy-and-hold abnormal return of $-25.9 \%$ (relative to size-and B/M-matched non-issuing stocks) into two components. One component, representing $41 \%$ of the total, is due to lower risk exposure. The second component, representing the remaining 59\%, is abnormal performance related to the surprise element of the issue decision, which the paper attributes to managers' private information that the market does not incorporate into the announcement return. This second component results in abnormal returns during the 16 months after the offering.
\end{abstract}

Keywords: managerial private information, investor underreaction, seasoned equity issues, long-run performance

JEL classification: $G 1, G 2, G 3$

\section{Introduction}

Seasoned equity issuers underperform benchmark stocks over the long run. ${ }^{1}$ We test the behavioural explanation for this finding, namely the underreaction hypothesis, which

We would like to thank the EFM editor, John A. Doukas, and, in particular, Jay Ritter, the referee, whose comments led to significant improvements in the paper. We also thank Michael Brennan, Ning Gao, Ian Garrett, Kai Li, Weimin Liu, Roberto Mura, and participants at the 2009 Spanish Finance Association meeting, the 2010 Midwest Finance Association meeting, and the 2010 Eastern Finance Association meeting for helpful comments. Correspondence: Pawel Bilinski.

${ }^{1}$ The discussion of Table 1 below cites relevant evidence. 
assumes that managers act rationally on their private information about stock overvaluation when announcing an equity issue. Investors underreact to the SEO announcement, stock mispricing persists at the issue date, and subsequent underperformance occurs as manager and investor valuations gradually converge. This is consistent with Loughran and Ritter's (1995, p. 48) statement that '... our numbers imply that if the market fully reacted to the information implied by an equity issue announcement, the average announcement effect would be -33 percent, not -3 percent.'

Our proxy for manager's private information about stock overvaluation is the inverse Mills ratio (lambda) from a probit model that predicts the issue decision based on publicly available information. Less anticipated SEO announcements have higher surprise components, implying greater stock overvaluation and giving higher lambdas. The underreaction hypothesis, therefore, states that higher lambdas predict lower postannouncement returns as the announcement effect fails to fully incorporate managers' private information.

For a sample of 2,879 equity issues in the USA over 1970-2004, we decompose an average three-year post-SEO buy-and-hold abnormal return of $-25.9 \%$, relative to size and book-to-market (size-B/M) non-issuing stocks, into two components. The first is a $-15.43 \%$ abnormal return related to the surprise element of the equity issue decision, which we attribute to investor underreaction to managers' private information revealed by the issue announcement. The second component of $-10.44 \%$ is due to lower postSEO risk exposure. We show that SEOs are larger, more liquid, with higher investment rates and $\mathrm{B} / \mathrm{M}$ ratios, and lower gearing and profitability than benchmark stocks after the offering. A detailed analysis of the underreaction to the issue shows that it corrects, on average, within 16 months. Thereafter, SEO returns are consistent with returns on similar assets. This gives a much shorter period of market correction than the five-years in Loughran and Ritter (1995) and Spiess and Affleck-Graves (1995).

The relation between post-issue returns and managers' private information is robust to controlling for pre-issue (abnormal) return performance, SEO attrition before the end of the holding period, delisting returns, and hot issue periods. The results are also robust to possible misspecification of the empirical model that could cause estimates of managerial private information to include public information affecting returns over a cross-section of stocks, since we find no relation between our estimate of managerial private information and returns for size- $\mathrm{B} / \mathrm{M}$ benchmarks or randomly drawn samples of non-issuing CRSP stocks.

This study decomposes SEO post-issue performance relative to size-B/M benchmarks into a short-term underreaction effect and a long-run discount rate effect. We propose an unbiased and consistent test of the underreaction story compared to previous studies that investigate whether investors rationally interpret publicly available information around the equity offering. A relation between public information and post-issue returns could reflect a relation that affects all stocks, rather than an effect specific to the equity issue. ${ }^{2}$ Consequently, past studies offer weak support for the underreaction hypothesis. Our tests control for the discount rate hypothesis, which says that lower risk explains low

\footnotetext{
${ }^{2}$ For example, Rangan (1998) attributes low SEO post-issue returns to investor underreaction to pre-issue earnings management. Xie (2001), however, finds that investors overprice discretionary accruals in a cross-section of stocks and high discretionary accruals predict low returns over the following two years. Xie (2001, p. 359) argues that '[discretionary accruals] mispricing is not limited to settings that give managers opportunistic incentives to manipulate earnings, such as before IPOs or seasoned equity offerings'.
} 
SEO returns. We show that SEO post-issue expected return estimates are biased and inconsistent in the absence of a formal model of managers' private information and their decision to make an SEO. In contrast to some previous findings, however, we find that a discount rate effect alone cannot explain SEO underperformance.

Evidence of less-than-rational investor behaviour around various corporate events suggests that adjusting for private information should accompany any cross-sectional regression of post-announcement returns. ${ }^{3}$ Our study has implications for related international research, since the literature documents SEO underperformance in non-US markets with different regulatory and institutional regimes and other equity flotation methods.

The paper proceeds as follows. The following section reviews previous literature that examines the underreaction and discount rate explanations for post-SEO returns and presents our empirical hypothesis. Section 3 develops an econometric model to test this hypothesis. Section 4 presents the data and we confirm previous evidence of SEO underperformance in Section 5. We test our hypothesis and present empirical results in Section 6. Section 7 examines the length of the delayed market reaction and Section 8 concludes.

\section{Previous Literature and Development of the Underreaction Hypothesis}

Several studies document abnormally low SEO returns up to five-years after equity issues. Table 1 summarises US and international evidence on long-run SEO performance using buy-and-hold abnormal returns. Underperformance ranges from $-9.0 \%$ over three years for German SEOs from 1960-1992 (Stehle et al., 2000) to -53.3\% over three years for Canadian SEOs from 1993-2004 (Carpentier et al., 2010) and to $-59.4 \%$ over five years for US SEOs from 1970-1990 (Loughran and Ritter, 1995).

Direct evidence on whether SEO underperformance is due to irrational investor behaviour around equity offerings is difficult to obtain. Previous studies investigate whether investors rationally interpret manager and analyst actions around equity offerings. Rangan (1998), Teoh et al. (1998), and DuCharme et al. (2004) show that increases in pre-issue discretionary accruals predict post-issue returns, consistent with investors incorrectly extrapolating pre-issue earnings performance. ${ }^{4}$ Shivakumar (2000), however, finds that the market rationally anticipates pre-issue earnings management and undoes its effect at the issue announcement. He argues that test misspecification explains Rangan's (1998) and Teoh et al.'s (1998) results. Jegadeesh (2000) suggests that investors are over-optimistic about issuers' future earnings at the issue date and adjust their expectations in response to disappointing earnings results after the issue. Jegadeesh reports that SEOs underperform by twice as much around post-issue quarterly earnings announcements as outside these periods. Brous et al. (2001), however, find no evidence of abnormal returns around quarterly post-issue earnings announcements. As most of these studies assume investor underreaction to publicly available information, failing to model investor reaction to managerial private information may explain their different results.

\footnotetext{
${ }^{3}$ See Subrahmanyam (2007) for a recent review of the behavioural finance literature.

${ }^{4}$ Iqbal et al. (2009) provide corresponding evidence on earnings management before UK open offers.
} 
Table 1

Previous evidence on the long-run performance of seasoned equity issuers

This table reports mean buy-and-hold abnormal returns from previous studies on the long-run performance following seasoned equity issues.

\begin{tabular}{|c|c|c|c|c|c|}
\hline Country & Study & $\begin{array}{l}\text { Sample } \\
\text { size }\end{array}$ & $\begin{array}{l}\text { Holding } \\
\text { period }\end{array}$ & $\begin{array}{l}\text { Sample } \\
\text { period }\end{array}$ & $\begin{array}{l}\text { Mean buy-and-hold } \\
\text { abnormal return (\%) }\end{array}$ \\
\hline Australia & Brown et al. (2010) & 1828 & 3 years & $1992-2006$ & $-14.4 \%$ \\
\hline Canada & Carpentier et al. (2010) & 958 & 3 years & 1993-2003 & $-53.3 \%$ \\
\hline France & Jeanneret (2005) & 232 & 3 years & 1984-1998 & $-18.2 \%$ \\
\hline Germany & Stehle et al. (2000) & 584 & 3 years & 1960-1992 & $-9.0 \%$ \\
\hline Japan & Cai and Loughran (1998) & 1389 & 5 years & $1971-1992$ & $-29.1 \%$ \\
\hline Spain & $\begin{array}{l}\text { Pastor-Llorca and } \\
\text { Martin-Ugedo (2004) }\end{array}$ & 44 & 3 years & 1989-1996 & $-13.7 \%$ \\
\hline UK & Levis (1995) & 203 & 1.5 years & $1980-1988$ & $-18.5 \%$ \\
\hline \multirow[t]{8}{*}{ US } & $\begin{array}{l}\text { Loughran and Ritter } \\
\text { (1995) }\end{array}$ & 3702 & 5 years & $1970-1990$ & $-59.4 \%$ \\
\hline & $\begin{array}{l}\text { Spiess and Affleck-Graves } \\
\text { (1995) }\end{array}$ & 1247 & 5 years & 1975-1989 & $-42.4 \%$ \\
\hline & $\begin{array}{l}\text { Mitchell and Stafford } \\
(2000)\end{array}$ & 4439 & 3 years & 1961-1993 & $-10.2 \%$ \\
\hline & Eckbo et al. (2000) & 3315 & 5 years & 1964-1995 & $-23.2 \%$ \\
\hline & Brav et al. (2000) & 3775 & 5 years & 1975-1992 & $-26.3 \%$ \\
\hline & Jegadeesh (2000) & 2992 & 5 years & $1970-1993$ & $-34.3 \%$ \\
\hline & Ritter $(2003)^{\mathrm{a}}$ & 7760 & 5 years & $1970-2000$ & $-16.67 \%$ \\
\hline & Billett et al. $(2011)^{\mathrm{b}}$ & 2942 & 3 years & $1983-2005$ & $-9.6 \%$ \\
\hline
\end{tabular}

${ }^{a}$ For Ritter (2003), five-year buy-and-hold abnormal returns are based on average annual returns in the five years after the issue for size-matched control firms.

${ }^{\mathrm{b}}$ For Billett et al. (2011), buy-and-hold abnormal returns are based on mean monthly abnormal returns from Fama-MacBeth regressions.

Information asymmetry between managers and investors allows managers to determine when the firm's stock is overpriced and use this information in their equity issue decisions. Investors form expectations of the likelihood and information content of equity issues using market and firm-specific information available before the offering. For example, investors can use accounting information, news reports, and stock price movements to assess the degree of firm misvaluation and the likelihood of managers making an equity offering. Stock prices should impound this information before the issue announcement. Bayesian investors should update their assessment of firm value based on managers' private information revealed by the announcement and stock prices should react fully and unbiasedly, so that SEOs earn normal post-issue returns. But if investors only partially discount the information in the issue announcement, post-issue SEO abnormal returns will be negative, as stock prices gradually adjust.

Figure 1 illustrates the relation between investor behaviour, managers' private information, and SEO stock price. Figure 1a shows the evolution of SEO stock price around the announcement if investors are rational. Investors predict an equity issue and impound the anticipated issue effect into the stock price before the announcement. ${ }^{5}$

${ }^{5}$ For simplicity, Figure 1 ignores SEO price run-up before the issue announcement. 

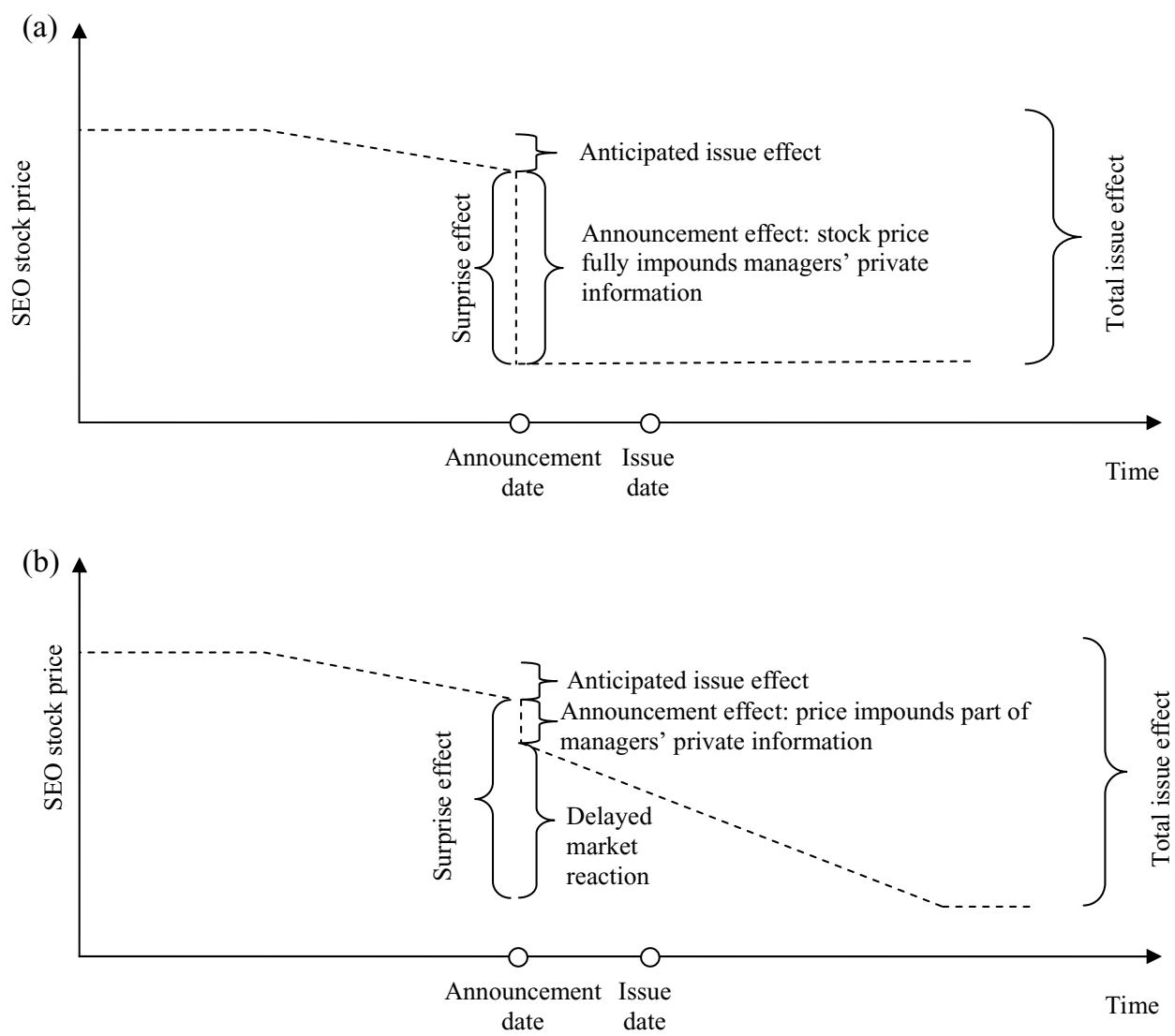

Fig. 1. The relation between managers' private information revealed at the issue announcement and SEO stock price

This figure depicts the relation between managers' private information revealed at the SEO announcement date and SEO stock price before and after the issue announcement for alternative types of investor behavior. Fig.1a shows the relation assuming investors act rationally and discount new information into stock price with no delay. Fig. 1b shows the relation when investors delay impounding managers' private information revealed at the issue announcement into the stock price.

On announcement, investors fully discount managers' private information and there is no long-run abnormal SEO performance. Figure $1 \mathrm{~b}$ shows the SEO price path when investors partially discount managers' private information at the announcement date. Stock price fully impounds the signal over a post-issue period, leading to SEO underperformance, consistent with the underreaction hypothesis. ${ }^{6}$ Once the stock price fully impounds the signal, SEO returns reflect post-issue risk. Figure 1 shows that testing the underreaction hypothesis is equivalent to testing for a significant negative relation between managers' private information and post-issue SEO buy-and-hold returns.

\footnotetext{
${ }^{6}$ Although the SEO announcement reveals managers' private information, empirical studies measure long-run SEO abnormal performance relative to the issue date. We follow this convention for comparability with previous studies.
} 
The underreaction hypothesis: lower post-issue SEO stock returns are associated with greater managerial private information revealed by the SEO announcement.

The underreaction hypothesis contrasts with the discount rate hypothesis, which says that reduced risk exposure explains low SEO returns. Eckbo et al. (2000) argue that SEO firms have lower leverage than size-B/M benchmarks, which reduces their risk exposure to unexpected inflation, the default spread, and changes in the slope of the term structure. Eckbo and Norli (2005) show that a liquidity-augmented Carhart (1997) model explains SEO five-year post-issue returns in calendar time. Lyandres et al. (2008) argue that firms raise equity to convert risky growth options into fixed assets, which lowers risk. They document that three-year post-issue returns load negatively on an investment factor, which explains their post-issue performance.

The evidence that reduced risk explains low SEO returns comes from calendar time analysis, which may have lower power to detect abnormal returns than event time analysis. Simulating events with more severe misvaluations in small stocks and high-volume periods, Loughran and Ritter (2000) report that Fama-French three-factor calendar time regressions capture only $50 \%$ of true abnormal returns, compared with $80 \%$ for event time buy-and-hold abnormal returns relative to size-B/M benchmarks. Ang and Zhang (2004) find in simulations that the power of Fama-French three-factor calendar time regressions 'decreases sharply as event horizon increases' (p. 255).

\section{A Model of Long-run SEO Abnormal Returns when Mispricing Causes the Rvent}

This section develops a model of long-run SEO abnormal returns when managers time issues of mispriced equity, investors underreact to the information revealed by the issue announcement, and the stock price fully impounds the information over a post-issue period. We start by describing the traditional estimator of abnormal returns when the source of abnormal performance is unknown. We call this the unconditional estimator of SEO abnormal return. To capture investor underreaction to managers' private information and prices impounding the information over a post-issue period, we then propose a conditional abnormal return estimator.

\subsection{The unconditional estimator of SEO abnormal returns}

A typical event study compares the return performance of an event firm to a counterfactual benchmark. To model this formally, consider issuing firm $i$ 's post-event return, $R_{1 i}$, in excess of the risk free rate, $R_{f}$, as a function of systematic risk, $X_{i}$, a firm specific component, $u_{1 i}$, and an event induced stock price reaction, $d_{1}$, where subscript 1 indicates the act of issuing. Similarly, the counterfactual return for SEO firm $i, R_{0 i}$, in excess of the risk free rate, $R_{f}$, is a function of risk, $X_{i}$, a firm specific component, $u_{0 i}$, and a non-event related performance, $d_{0}$, where subscript 0 indicates the act of not issuing. The counterfactual state is the hypothetical state in which an equity issuer chooses not to issue, and the event window that defines $R_{1 i}$ and $R_{0 i}$ usually spans three to five years. Two outcome equations give the post-event expected returns

$$
E\left(R_{1 i}-R_{f} \mid X_{i}\right)=d_{1}+X_{i} \beta_{1}+E\left(u_{1 i}\right) \text { for firm } i \text { in the act of issuing }
$$

$$
E\left(R_{0 i}-R_{f} \mid X_{i}\right)=d_{0}+X_{i} \beta_{0}+E\left(u_{0 i}\right) \text { for firm } i \text { in the act of not issuing }
$$


The unconditional issue effect is the difference between equations (1) and (2), where 'unconditional' denotes that returns are not conditioned on managers' issue decision. In the general case where the equity offering changes the issuer's risk, this is

$$
E\left(R_{1 i} \mid X_{i}\right)-E\left(R_{0 i} \mid X_{i}\right)=d_{1}-d_{0}+X_{i}\left(\beta_{1}-\beta_{0}\right)
$$

where a negative $d_{1}-d_{0}$ corresponds to SEO underperformance. While equation (3) is the commonly estimated (pooled) cross-sectional regression, it fails to model the source of abnormal performance, $d_{1}-d_{0}$.

\subsection{A conditional estimator of SEO returns}

To generate unbiased and consistent estimates of SEO post-issue risk exposure and test the underreaction hypothesis, we model managers' issue decision. Managers issue equity based on their assessment of the offering's expected benefits, $D_{i}^{*}$. The equity issue selection equation models $D_{i}^{*}$ as a function of observable and unobservable components, $Z_{i} \gamma$ and $u_{d i}$,

$$
D_{i}^{*}=Z_{i} \gamma+u_{d i}
$$

The component $Z_{i} \gamma$ captures the issue benefits that both managers and investors observe. For example, managers and investors can use market and accounting measures to assess the value of positive NPV projects available to the firm, the average return on investment expected from exercising growth options, and the equity dilution cost to old shareholders of issuing new shares. The component $u_{d i}$ captures the issue benefits observed by managers alone, i.e. managers' private information. In line with the underreaction hypothesis, $u_{d i}$ captures the benefit of issuing overvalued equity.

Firms announce an equity issue, $D_{i}=1$, only if the expected issue benefits are positive, $D_{i}^{*} \geq 0$, where the normalised threshold is zero. Investors observe the issue decision and the component $Z_{i} \gamma$. They do not observe $u_{d i}$ but can infer it from the issue decision. For example, they can infer from a firm's decision to issue that $u_{d i}$ must be high if $Z_{i} \gamma$ is too low to justify the offering. Similarly for non-issuers, high anticipated issue benefits, $Z_{i} \gamma$, are likely to be associated with low $u_{d i}$ for the expected issue benefits to remain negative.

We observe returns in the issue (non-issue) state if the expected benefits are positive (negative), $D_{i}=1$ iff $D_{i}^{*} \geq 0\left(D_{i}=0\right.$ iff $\left.D_{i}^{*}<0\right)$, which implies that SEO post-issue returns are conditional on $D_{i}^{*}$. Accordingly, the conditional expected SEO excess returns are

$$
\begin{aligned}
& E\left(R_{1 i}-R_{f} \mid X_{i}, D_{i}^{*} \geq 0\right)=X_{i} \beta_{1}^{\prime}+E\left(u_{1 i} \mid u_{d i}+Z_{i} \gamma \geq 0\right) \\
& E\left(R_{0 i}-R_{f} \mid X_{i}, D_{i}^{*}<0\right)=X_{i} \beta_{0}^{\prime}+E\left(u_{0 i} \mid u_{d i}+Z_{i} \gamma<0\right)
\end{aligned}
$$

for firm $i$ in the acts of issuing and not issuing. ${ }^{7}$ In simple terms, expected SEO post-issue performance depends on risk and a conditional error term. If the

\footnotetext{
${ }^{7}$ When $u_{1 i}$ and $u_{0 i}$ are correlated with $u_{d i}$, i.e., when investors underreact to managers' private information revealed by the issue and $\operatorname{corr}\left(u_{d i}, X_{i}\right) \neq 0$, equations (5) and (6) give unbiased and consistent estimators of $\beta^{\prime}$. This follows from directly modelling manager's endogenous decision to issue and including its effect in the regression specification based on equations (5) and (6), which corrects for the omitted variables bias.
} 
underreaction hypothesis holds, post-issue abnormal performance is due to prices gradually incorporating managers' private information, $u_{d i}$, i.e., $E\left(u_{1 i} \mid u_{d i}+Z_{i} \gamma \geq 0\right) \neq 0$ and $E\left(u_{0 i} \mid u_{d i}+Z_{i} \gamma<0\right) \neq 0$.

\subsection{Estimating the return effect of managers' private information}

To estimate equations (5) and (6), we assume bivariate normal distributions for $u_{1 i}, u_{d i}$ and $u_{0 i}, u_{d i}$ with covariances $\sigma_{u_{d} u_{1}}$ and $\sigma_{u_{d} u_{0}}$, which transforms equations (5) and (6) to

$$
\begin{gathered}
E\left(R_{1 i}-R_{f} \mid X_{i}, D_{i}^{*} \geq 0\right)=X_{i} \beta_{1}^{\prime}+E\left(u_{1 i} \mid u_{d i} \geq-Z_{i} \gamma\right) \\
=X_{i} \beta_{1}^{\prime}+\sigma_{u_{d} u_{1}} \frac{\phi\left(-Z_{i} \gamma / \sigma_{u_{d}}\right)}{1-\Phi\left(-Z_{i} \gamma / \sigma_{u_{d}}\right)} \\
=X_{i} \beta_{1}^{\prime}+\sigma_{u_{d} u_{1}} \frac{\phi\left(Z_{i} \gamma / \sigma_{u_{d}}\right)}{\Phi\left(Z_{i} \gamma / \sigma_{u_{d}}\right)}=X_{i} \beta_{1}^{\prime}+\sigma_{u_{d} u_{1}} \lambda_{1 i} \\
E\left(R_{0 i}-R_{f} \mid X_{i}, D_{i}^{*}<0\right)=X_{i} \beta_{0}^{\prime}+E\left(u_{0 i} \mid u_{d i}<-Z_{i} \gamma\right) \\
=X_{i} \beta_{0}^{\prime}+\sigma_{u_{d} u_{0}} \frac{-\phi\left(Z_{i} \gamma / \sigma_{u_{d}}\right)}{1-\Phi\left(Z_{i} \gamma / \sigma_{u_{d}}\right)} \\
=X_{i} \beta_{0}^{\prime}+\sigma_{u_{d} u_{0}} \lambda_{0 i}
\end{gathered}
$$

where $\phi($.$) and \Phi($.$) are the standard normal pdf and cdf and \lambda_{1 i}$ and $\lambda_{0 i}$ are inverse Mills ratios. Equations (7) and (8) are standard representations of Heckman's (1979) sample selection adjustment, but we show that the inverse Mills ratios also measure the announcement date information revealed by managers.

In equations (7) and (8), $\sigma_{u_{d} u_{1}} \lambda_{1 i}$ and $\sigma_{u_{d} u_{0}} \lambda_{0 i}$ capture the effect of information revealed by the issue announcement and non-announcement on subsequent performance. ${ }^{8}$ The size of the stock price adjustment after the issue depends on the amount of private information $u_{d i}$ (since low $Z_{i} \gamma$ means high $u_{d i}$ to reach the issue threshold, which in turn leads to high $\left.\lambda_{1 i}\right),{ }^{9}$ on the strength of the correlation between the error terms in the selection equation (4) and outcome equations (1) and (2) $\left(\sigma_{u_{d} u_{1}}=\rho_{1} \sigma_{u_{d}} \sigma_{u_{1 i}}\right.$ and $\sigma_{u_{d} u_{0}}=\rho_{0} \sigma_{u_{d}} \sigma_{u_{0 i}}$ for the issue and non-issue states), and on the variances of $u_{d i}, u_{1 i}$, and $u_{0 i}$. Intuitively, the correlation coefficients $\rho_{1}$ and $\rho_{0}$ measure the proportion of the announcement date information that stock prices impound after the issue. Perfect correlation means post-issue returns reflect all the announcement date information and zero correlation means stock prices fully impound managerial information at the offering announcement. With high variation in the magnitude of private information, $\sigma_{u_{d}}$, a larger $u_{d i}$ is more likely. Larger $u_{d i}$ means larger benefits of issuing overvalued equity, consistent with greater misvaluation. High return volatility, $\sigma_{u_{1 i}}$ and $\sigma_{u_{0 i}}$, is commonly associated with high firm value uncertainty and potentially larger stock mispricing.

\footnotetext{
${ }^{8}$ Scaling $-Z_{i} \gamma$ by the cross-sectional standard deviation of manager's private information, $\sigma_{u_{d}}$, ensures comparability of $u_{d i}$ across firms and normalises its variance to one.

${ }^{9}$ For a given $Z_{i} \gamma$, if a firm issues, investors can infer that $u_{d i}$ is larger than in the non-issue state to reach the threshold $Z_{i} \gamma+u_{d i} \geq 0$. As $Z_{i} \gamma$ falls, $u_{d i}$ needs to be higher to reach the threshold, leading to a larger $\lambda_{1 i}$.
} 
Subtracting equation (8) from equation (7) gives the conditional issue effect

$$
E\left(R_{1 i} \mid X_{i}, D_{i}^{*} \geq 0\right)-E\left(R_{0 i} \mid X_{i}, D_{i}^{*}<0\right)=\sigma_{u_{d} u_{1}} \lambda_{1 i}-\sigma_{u_{d} u_{0}} \lambda_{0 i}+X_{i}\left(\beta_{1}^{\prime}-\beta_{0}^{\prime}\right)
$$

where $\sigma_{u_{d} u_{1}} \lambda_{1 i}-\sigma_{u_{d} u_{0}} \lambda_{0 i}$ is the post-event stock price adjustment in the issue vs. non-issue states as the market impounds the information $u_{d i}$, and $X_{i}\left(\beta_{1}^{\prime}-\beta_{0}^{\prime}\right)$ is the differential risk exposure. Unlike equation (3), equation (9) distinguishes the behavioural explanation for low SEO returns (investor underreaction) from the rational (risk-based) explanation, allowing a test of the underreaction hypothesis. The hypothesis predicts a negative relation between post-issue returns and the surprise component of the issue announcement, $\lambda_{1 i}$, reflecting managers' information about stock mispricing. If the underreaction hypothesis is true, $\sigma_{u_{d} u_{1}}$ should be negative for equity issuers. Intuitively, a highly unexpected issue conveys more information and post-issue abnormal performance should be lower. Equation (9) also provides an unbiased and consistent test of the discount rate effect. If issuing lowers risk, a discount rate effect corresponds to $X_{i}\left(\beta_{1}^{\prime}-\beta_{0}^{\prime}\right)<0$.

To control for SEO returns in the non-issue state, following Spiess and AffleckGraves (1995) and other studies, we use size-B/M matched control firms. ${ }^{10}$ As benchmark stocks do not announce a non-issue decision and issue decisions are largely unexpected, we predict an insignificant relation between $\sigma_{u_{d}} u_{0}$ and benchmark stock returns.

Loughran and Ritter (1995) and Spiess and Affleck-Graves (1995) find that it takes up to five years for the initial underreaction to SEO announcements to disappear. This is at odds with empirical evidence that suggests irrational investor behaviour is more short-lived. For example, Michaely et al. (1995) find that stocks announcing dividend initiations or omissions exhibit abnormal stock performance over the following twelve months. Womack (1996) finds that the initial underreaction to unfavorable changes in analyst recommendations corrects within six months. Bernard and Thomas (1989) report that the initial underreaction to earnings announcements corrects within three quarters. A more likely scenario for SEOs, therefore, is that stock prices fully impound managers' private information well within five years and a discount rate effect dominates over the remaining holding period. To estimate how rapidly prices impound the issue signal, we vary the return holding period. Once stock prices fully impound the signal, we should find no relation between lambda and issuer returns.

While the underreaction hypothesis predicts that investors underreact to private information about stock mispricing revealed by the issue, investors could also underreact to public information on firm mispricing. For example, investors may only partially discount the information contained in abnormal stock return performance before the announcement. Including this information in the regression controls for any delayed reaction to public information.

\subsection{Empirical specification issues}

The empirical validity of model (9) hinges on accurately identifying the systematic component of the equity issue decision in equation (4), $Z_{i} \gamma$. If the equity issue decision

\footnotetext{
${ }^{10}$ Baker and Wurgler (2000) argue that managers can time not only individual stock mispricing, but also market-wide mispricing. Size-B/M matching over the post-issue period also controls for market-wide mispricing.
} 
model excludes publicly available information, it becomes part of the error term and lambda. To check whether lambda captures public information omitted from $Z_{i} \gamma$, we conduct two tests. First, we test whether lambda predicts the returns of size-B/M benchmark stocks. Second, we relate lambda to returns of random samples of nonissuing stocks. An insignificant relation between lambda and benchmark or non-issuer stock returns suggests that there is no significant public information component in lambda and no misspecification of the empirical model in equation (4).

\section{Data and Sample Selection Criteria}

Our sample of seasoned equity offerings is from the SDC New Issues database. The sample period is January 1970 to December 2007. To allow for a three-year holding period, the last offering is in December 2004. The sample includes all CRSP US domiciled companies listed on NYSE/AMEX/Nasdaq at the time of the SEO that issue pure primary shares or combinations of primary and equity sales by a major shareholder (combinations) in the US market. We include industrial, financial, and utility firms but exclude unit offerings and SEOs that simultaneously offer debt, preferred stock, or warrants. We exclude private placements, exchange offers of stock, 144A offers, cancelled offers, and spin-off related issues. We also exclude SEOs within three years of an IPO to prevent IPO underperformance influencing the results. These criteria lead to an initial sample of 8,223 issues. Excluding equity offerings by the same company that occur within the three-year holding period of the first equity offering, reduces the sample to 5,121. Retaining offerings of common stock only (CRSP share codes 10 and 11) with stock return data available for at least a month after the issue leaves 4,931 issues. ${ }^{11}$ Obtaining a conditional estimator of abnormal returns requires non-missing CRSP/Compustat annual data for two fiscal years before the issue. We use accounting data for the fiscal year ending at least six months before the issue date, leaving 3,047 SEOs. ${ }^{12}$ Following Loughran and Ritter (1995) and Spiess and Affleck-Graves (1995), we use only issuers and benchmark stocks with positive equity book values in the matching process, which reduces the sample to 2,879 SEOs for which we find control stocks. NYSE/AMEX and Nasdaq listed stocks on CRSP that have not issued new equity for the past three years provide a pool of potential matching stocks.

Table 2 reports the distribution of the SEOs across NYSE/AMEX and Nasdaq exchanges, broad industry groups (financial, industry, and utility), nine Fama and French size and $\mathrm{B} / \mathrm{M}$ portfolios, and issue period. Of the 2,879 SEOs, $46.58 \%$ list on NYSE/AMEX and $53.42 \%$ on Nasdaq. Industrial issuers are the largest group, with 2,498 SEOs. Splitting issuers into three portfolios, small $(S)$, medium $(M e)$, and big $(B)$ by market value of common equity using NYSE breakpoints, 1,489 are small capitalisation firms. A corresponding split on $\mathrm{B} / \mathrm{M}$ into high $(H)$, medium $(M)$, and low $(L)$ gives 1,148 low B/M stocks, of which 534 are small. Previous studies document that small, low $\mathrm{B} / \mathrm{M}$ stocks, which are subject to larger valuation errors and more susceptible to misvaluation, dominate equity issuers (e.g., Brav et al., 2000, Table 2). The number of

\footnotetext{
${ }^{11}$ Using CRSP share codes 10 and 11 excludes closed-end funds and REITs.

${ }^{12}$ To match an SEO with a non-issuing control firm, we use book value of equity for the fiscal year two years before the issue if the offering is in the first six months of the year and book value for the previous fiscal year for offers in the second six months of the year.
} 
Table 2

Distribution of SEOs over the sample period 1970-2004

This table shows the distribution of 2,879 SEOs across NYSE/AMEX and Nasdaq stocks, three industry groups (Financial, Industrial and Utility), Fama and French size (Small, $S$, Medium, Me, Big, $B$ ) and B/M (High, H, Medium, $M$, Low, $L$ ) portfolios, issue period (1970-1979, 1980-1989, 1990-1999, 2000-2004), and as a percentage of the full sample. The sample includes US domiciled companies from CRSP, listed on NYSE/AMEX/Nasdaq at the time of the issue, that make offerings of pure primary shares or combinations of primary and equity sales by a major shareholder (combinations) in the US market. We include industrial, financial, and utility firms but exclude unit offerings and SEOs that simultaneously offer debt, preferred stock, or warrants. The sample excludes private placements, exchange offers of stock, 144A offers, cancelled offers, spin-off related issues, SEOs within a threeyear period of an IPO, and equity offerings by the same company that occur within the three-year holding period of a prior equity offering. We retain offerings of common stock only (CRSP share codes 10 and 11) with stock return data available for at least a month after the issue and with non-missing CRSP/Compustat annual data for the conditional estimator of SEO abnormal returns for two fiscal years before the issue. We use only issuers and benchmark stocks with positive equity book values in the matching process.

\begin{tabular}{lrr}
\hline & SEOs & \% of the full sample \\
\hline Total & 2879 & \\
NYSE/AMEX & 1341 & 46.58 \\
Nasdaq & 1538 & 53.42 \\
Financial & 127 & 4.41 \\
Industrial & 2498 & 86.77 \\
Utility & 254 & 8.82 \\
FF $S-L$ & 534 & 18.55 \\
FF $S-M$ & 511 & 17.75 \\
FF $S-H$ & 444 & 15.42 \\
FF $M e-L$ & 401 & 13.93 \\
FF $M e-M$ & 304 & 10.56 \\
FF $M e-H$ & 173 & 6.01 \\
FF $B-L$ & 213 & 7.40 \\
FF $B-M$ & 186 & 6.46 \\
FF $B-H$ & 113 & 3.92 \\
$1970-1979$ & 169 & 5.87 \\
$1980-1989$ & 578 & 20.08 \\
$1990-1999$ & 1048 & 36.40 \\
$2000-2004$ & 1084 & 37.65 \\
\hline
\end{tabular}

issuers increases over time, with 169 SEOs occurring in the 1970s and 1,084 between 2000 and $2004 .^{13}$

${ }^{13}$ The lower number of SEOs in the early sample period is partly due to Nasdaq data being unavailable on CRSP before December 1972 and less complete Compustat coverage in the 1970s. 


\section{The Long-run Performance of SEOs: Unconditional Estimates of the Issue Effect}

Barber and Lyon (1997) show that tests using buy-and-hold abnormal returns and size-B/M matches are well specified, and studies of SEO underperformance largely follow this design. ${ }^{14}$ We replicate matching based on the closest neighbour approach. Of non-issuing firms within a 30\% range of the issuer's market value at the year-end before the offering, we select a matching firm with the closest B/M to the issuer's. Non-issuers are companies that are not listed as equity issuers on the SDC New Issues database for the past three years. The definition of B/M follows Fama and French (1992). Each control stock pairs with one SEO over the three-year holding period. If a control stock delists or issues equity, we choose a new match from the original list of eligible controls. If an issuing firm delists, we truncate the SEO and its match return on that date.

Sample firm $i$ 's $t_{i}$-month buy-and-hold return (BHR) is $B H R_{i}=\prod_{\tau=1}^{t_{i}}\left(1+R_{i \tau}\right)-1$, starting at the beginning of the first calendar month after the issue and finishing at the earlier of the three-year anniversary or the delisting date. The average holding period return across $N$ sample stocks is $\overline{B H R}=\sum_{i=1}^{N} x_{i} B H R_{i}$ where $x_{i}$ denotes equally weighted (EW) or value-weighted (VW). Value weights are market capitalisations scaled by the S\&P 500 stock market index one month before the offer to ensure that early and late sample observations have consistent weights.

Table 3 reports average BHRs for issuers and their matches over a three-year holding period. Column Diff, denoting the difference between these two figures, gives issuers' buy-and-hold abnormal return (BHAR). Panel A shows EW and VW results. The average BHAR using EW is $-25.87 \%$ and $-22.6 \%$ using VW. Underperformance is significant in all specifications at $1 \%$ based on skewness-adjusted $t$-statistics recommended by Lyon et al. (1999).

We previously argued that abnormal performance following equity issues should be relatively short-lived, as investors correct their valuations and stock prices impound the announcement date signal. We test this prediction in Table 3, Panel B where we increase the return holding period one month at a time. BHARs are $-11.33 \%$ for a one-year holding period, $-21.34 \%$ for a two-year holding period, and $-25.87 \%$ for a three-year holding period. The geometric average abnormal monthly return over the first sixteen months following the issue is $-1.054 \%$, while it is $-0.834 \%$ over the next ten months, and $-0.459 \%$ over the last ten months of the three-year holding period. ${ }^{15}$ This suggests SEO underperformance concentrates shortly after the offering. ${ }^{16}$

\footnotetext{
${ }^{14}$ Calendar time regressions using Fama and French's (1993) model also record SEO underperformance (Loughran and Ritter, 1995, 2000, Lyandres et al., 2008, Eckbo et al., 2000).

${ }^{15}$ Loughran and Ritter (1995) document strong SEO underperformance relative to sizematched control firms over months 7-18 after the issue. They report less negative issuer abnormal performance over months 19-60.

${ }^{16}$ Ritter (2003, Table 1) finds that a sample of 6,638 SEOs over 1970-2000 have average buyand-hold abnormal returns of $2 \%$ compared to size-B/M control firms in the six months after the issue. Relative to Ritter's sample, we exclude SEOs within 36 months of an IPO, multiple issues, and SEOs without necessary Compustat data. Over 1970-1990, these additional data requirements increase average SEO market capitalisation by $19.62 \%$ and lower issuer performance to an (insignificant) $-2.38 \%$. Lifting the restrictions gives an insignificant six-month BHAR of $1.98 \%$.
} 
Table 3

Unconditional stock performance following seasoned equity offerings

Panel A reports equally-weighted (EW) and value-weighted (VW) buy-and-hold returns (in \%) for 2,879 equity issuers (Issuer), size-B/M matched control firms (Match), and their difference (Diff) over a three-year post-issue period starting at the beginning of the first calendar month after the issue and finishing at the earlier of the three-year anniversary or the delisting date. $p$ is the $p$-value based on a skewness-adjusted $t$-statistic testing the hypothesis of no difference between average longrun performance of issuers and their matches. In calculating value weights we standardise market capitalisation by the S\&P 500 stock market index to ensure comparability over time. Panel B reports EW SEO and benchmark performance where we increase the holding period from 1 to 36 months after the issue.

\begin{tabular}{|c|c|c|c|c|}
\hline Weight/Holding period & Issuer $(\%)$ & Match $(\%)$ & Diff $(\%)$ & $p$ \\
\hline \multicolumn{5}{|c|}{ Panel A: Unconditional SEO performance for three years after the issue } \\
\hline EW & 14.94 & 40.81 & -25.87 & 0.000 \\
\hline VW & 21.37 & 43.98 & -22.60 & 0.000 \\
\hline \multicolumn{5}{|c|}{ Panel B: EW long-run SEO performance as the holding period increases } \\
\hline $0-1$ & 0.70 & 0.59 & 0.10 & 0.776 \\
\hline $0-2$ & -0.13 & 0.99 & -1.12 & 0.022 \\
\hline $0-3$ & -0.14 & 1.84 & -1.98 & 0.001 \\
\hline $0-4$ & -1.06 & 2.31 & -3.36 & 0.000 \\
\hline $0-5$ & -1.64 & 3.26 & -4.91 & 0.000 \\
\hline $0-6$ & -1.12 & 4.37 & -5.50 & 0.000 \\
\hline $0-7$ & -1.09 & 5.47 & -6.56 & 0.000 \\
\hline $0-8$ & -0.92 & 6.46 & -7.38 & 0.000 \\
\hline $0-9$ & -0.91 & 7.42 & -8.33 & 0.000 \\
\hline $0-10$ & -1.40 & 8.20 & -9.60 & 0.000 \\
\hline $0-11$ & -1.55 & 9.19 & -10.74 & 0.000 \\
\hline $0-12$ & -1.40 & 9.93 & -11.33 & 0.000 \\
\hline $0-13$ & -1.57 & 11.49 & -13.06 & 0.000 \\
\hline $0-14$ & -0.99 & 13.46 & -14.45 & 0.000 \\
\hline $0-15$ & -0.86 & 14.51 & -15.38 & 0.000 \\
\hline $0-16$ & -0.44 & 15.16 & -15.60 & 0.000 \\
\hline $0-17$ & -0.10 & 16.50 & -16.60 & 0.000 \\
\hline $0-18$ & 0.84 & 17.46 & -16.62 & 0.000 \\
\hline $0-19$ & 1.76 & 18.69 & -16.92 & 0.000 \\
\hline $0-20$ & 1.60 & 19.80 & -18.21 & 0.000 \\
\hline $0-21$ & 2.68 & 21.37 & -18.69 & 0.000 \\
\hline $0-22$ & 3.21 & 22.27 & -19.06 & 0.000 \\
\hline $0-23$ & 3.72 & 23.50 & -19.78 & 0.000 \\
\hline $0-24$ & 3.80 & 25.14 & -21.34 & 0.000 \\
\hline $0-25$ & 4.39 & 26.38 & -21.99 & 0.000 \\
\hline $0-26$ & 5.16 & 27.54 & -22.38 & 0.000 \\
\hline $0-27$ & 5.80 & 29.40 & -23.61 & 0.000 \\
\hline $0-28$ & 7.06 & 29.96 & -22.90 & 0.000 \\
\hline $0-29$ & 8.16 & 30.81 & -22.65 & 0.000 \\
\hline $0-30$ & 9.63 & 32.57 & -22.94 & 0.000 \\
\hline $0-31$ & 10.44 & 33.92 & -23.48 & 0.000 \\
\hline $0-32$ & 10.77 & 35.43 & -24.67 & 0.000 \\
\hline $0-33$ & 11.56 & 36.71 & -25.16 & 0.000 \\
\hline $0-34$ & 12.64 & 38.26 & -25.62 & 0.000 \\
\hline $0-35$ & 13.99 & 39.28 & -25.29 & 0.000 \\
\hline $0-36$ & 14.94 & 40.81 & -25.87 & 0.000 \\
\hline
\end{tabular}


The unconditional estimator of abnormal returns in equation (3) highlights the differential risk exposure of SEOs and benchmark stocks as a potential explanation of issuer underperformance. Previous studies suggest that post-offering SEO performance relates to a number of risk factors and market characteristics. These include the issuer's equity market value and $\mathrm{B} / \mathrm{M}$ ratio, leverage (Eckbo et al., 2000), stock liquidity (Eckbo and Norli, 2005), and investment rates (Lyandres et al., 2008). In addition to these characteristics, we control for firm profitability measured by return on assets. Chen et al. (2010), building on the $q$-theory of investment (Tobin, 1969; Cochrane, 1991), link discount rates to firm investment and profitability. This is because, given a firm's profitability, a low discount rate means high net present values of new projects, which stimulates new investment. They propose a three factor model in which market, investment, and profitability factors explain a wide cross-section of stock returns and several anomalies that the Fama and French (1993) and Carhart (1997) models fail to capture. Finally, the timing hypothesis predicts equity issues follow abnormal stock price performance. We use the market-adjusted stock return over the six pre-issue months to proxy for a firm's pre-issue misvaluation. ${ }^{17}$

Table 4, Panel A verifies the above predictions by reporting results of a regression with three-year BHRs of SEOs or their matches as the dependent variable. The independent variables include, in log form, book-to-market ratio $(B / M)$, equity market value $(M V)$, leverage $(L E V)$, and illiquidity level $(L M 12) .{ }^{18} L E V$ is the ratio of total liabilities to total assets. LM12 is Liu's (2006) trading discontinuity measure of liquidity, which builds on the intuition that a large number of no trading days indicates trading discontinuity and the potential difficulty in executing an order, and the turnover adjustment captures the ability to trade large quantities of stock. ${ }^{19}$ Liu (2010) shows that LM12 captures multiple liquidity dimensions and that it generates a more robust liquidity premium than the bid-ask spread, Hasbrouck's (2009) Gibbs estimate of stock transactions costs, Lesmond et al.'s (1999) number of zero daily returns, stock turnover, and Amihud's (2002) return-to-volume measure. The independent variables also include the investment-to-assets ratio $(I N V / A)$, return on assets $(R O A)$, and pre-issue abnormal performance $(p A B) . I N V / A$ is the change in property plant and equipment plus the annual change in inventories scaled by lagged asset value. $R O A$ is income before extraordinary items over lagged asset value. $p A B$ is the difference between the firm's and the CRSP VW NYSE/AMEX/Nasdaq index buy-and-hold returns over the six months before the issue. $B / M, L E V, R O A$ and $I N V / A$ are measured in December at

\footnotetext{
${ }^{17}$ Descriptive statistics for these variables and the variables related to the equity issue decision are in Table 5.

${ }^{18}$ Market values in all regressions are deflated by the S\&P 500 market index to give comparability over time.

${ }^{19}$ Liu (2006, p.635) defines LM12 as the standardised turnover-adjusted number of zerotrading volume days over the prior 12 months, (number of zero volume days in prior 12 months $+(1 /($ TR12 $\times$ Deflator $))) \times((21 \times 12) /$ NoTD $)$, where TR12 is the sum of daily turnover (in percentage) over the prior 12 months, Deflator $=20,000$ to ensure that $1 /$ TR12 $\times$ Deflator $<1$, and NoTD is the number of trading days over the prior 12 months; $(21 \times 12) /$ NoTD standardises the number of trading days in a month to 21 . Sorting stocks on $L M 12$ is equivalent to a first sort on the number of zero daily trading volumes with a turnover sort resolving any ties, where the latter applies primarily to frequently traded stocks with zero non-trading days.
} 
Table 4

Regressions of buy-and-hold returns on pre-event firm and market characteristics

Panel A reports regression estimates (Estimate) for equations (1) and (2) where the dependent variable is the three-year buy-and-hold return of SEOs or their matches. The explanatory variables are bookto-market $(B / M)$, total market capitalisation in \$m deflated by the S\&P 500 market index $(M V)$, Liu's (2006) liquidity measure ( $L M 12)$, and leverage $(L E V)$, all in log form, investment-to-assets $(I N V / A)$, return on assets $(R O A)$ and pre-issue abnormal return performance $(p A B) . M V, L M 12$ and $p A B$ are measured one month before the issue. $B / M, L E V, R O A$ and $I N V / A$ are for the prior fiscal year-end at least six months before the issue and, together with $L M 12$, are winsorised based on the CRSP population at $\pm 1 \%$. $S E$ denotes year- and industry-clustered standard errors and $p$ the $p$-value. $N$ is the number of observations, $F$ and $P>F$ are the $F$ - and corresponding $p$-values for model specification and $\operatorname{Adj} R^{2}$ is the adjusted R-square. Panel B shows the difference in coefficients between SEOs and control stocks (Beta diff) and mean firm characteristics for SEOs (X SEO), matches ( $X$ matches) and their difference $(X$ diff $)$. Average firm characteristics are over a 3-year post-issue holding period. $S E$ denotes year- and industry-clustered standard errors and $p$ is a $p$-value for the significance of the differences.

Panel A: Regression estimates for equations (1) and (2)

\begin{tabular}{|c|c|c|c|c|c|c|}
\hline & \multicolumn{3}{|c|}{ SEOs } & \multicolumn{3}{|c|}{ Matches } \\
\hline & Estimate & $S E$ & $p$ & Estimate & $S E$ & $p$ \\
\hline Intercept & 0.436 & 0.065 & 0.000 & 0.618 & 0.051 & 0.000 \\
\hline $\ln B / M$ & 0.092 & 0.039 & 0.017 & 0.189 & 0.018 & 0.000 \\
\hline $\ln M V$ & 0.028 & 0.011 & 0.013 & -0.018 & 0.023 & 0.431 \\
\hline $\ln L M 12$ & -0.003 & 0.004 & 0.378 & -0.011 & 0.005 & 0.028 \\
\hline $\ln L E V$ & 0.145 & 0.022 & 0.000 & 0.131 & 0.039 & 0.001 \\
\hline$I N V / A$ & -0.402 & 0.076 & 0.000 & -0.359 & 0.124 & 0.004 \\
\hline$R O A$ & 0.329 & 0.100 & 0.001 & 0.633 & 0.115 & 0.000 \\
\hline$p A B$ & -0.094 & 0.024 & 0.000 & -0.002 & 0.072 & 0.973 \\
\hline$N$ & 2879 & & & & & \\
\hline$F$ & 26.370 & & & $F$ & 25.840 & \\
\hline$P>F$ & 0.000 & & & $P>F$ & 0.000 & \\
\hline $\operatorname{Adj} R^{2}$ & $3.44 \%$ & & & Adj $R^{2}$ & $4.03 \%$ & \\
\hline
\end{tabular}

Panel B: Differences in coefficients and firm characteristics

\begin{tabular}{|c|c|c|c|c|c|c|c|c|}
\hline & \multicolumn{3}{|c|}{ Coefficient differences } & \multicolumn{2}{|c|}{ Variable means } & \multicolumn{3}{|c|}{ Characteristic differences } \\
\hline & Beta diff & $S E$ & $p$ & $X S E O$ & $X$ matches & $X$ diff & $S E$ & $p$ \\
\hline Intercept & -0.182 & 0.082 & 0.027 & & & & & \\
\hline $\ln B / M$ & -0.097 & 0.043 & 0.023 & -0.699 & -0.723 & 0.024 & 0.011 & 0.020 \\
\hline $\ln M V$ & 0.046 & 0.026 & 0.071 & -0.596 & -0.795 & 0.199 & 0.011 & 0.000 \\
\hline $\ln L M 12$ & 0.008 & 0.006 & 0.229 & -7.685 & -6.071 & -1.614 & 0.062 & 0.000 \\
\hline $\ln L E V$ & 0.014 & 0.044 & 0.744 & -0.905 & -0.875 & -0.030 & 0.012 & 0.015 \\
\hline$I N V / A$ & -0.043 & 0.145 & 0.768 & 0.125 & 0.078 & 0.047 & 0.004 & 0.000 \\
\hline$R O A$ & -0.304 & 0.152 & 0.046 & -0.022 & 0.018 & -0.040 & 0.003 & 0.000 \\
\hline$p A B$ & -0.091 & 0.076 & 0.231 & & & & & \\
\hline
\end{tabular}


least six months before the issue. $M V$ and $L M 12$ are measured one month before the issue. Accounting variables and LM12 are winsorised based on the CRSP population at $\pm 1 \%$.

The results show no relation between SEO long-run performance and pre-issue stock liquidity. ${ }^{20}$ Larger issuers and issuers with higher $\mathrm{B} / \mathrm{M}$ ratios earn higher post-issue returns. The positive coefficient on leverage confirms results in Eckbo et al. (2000) that increased leverage and a resultant higher exposure to default risk leads to higher realised rates of return for equity holders. The coefficient on $I N V / A$ is negative, consistent with Lyandres et al. (2008). As in Chen et al. (2010), higher profitability increases stock returns. A significant relation between SEO long-run returns and $p A B$ suggests that stock prices do not fully impound publicly available information about firm misvaluation at the announcement date. Matching stocks' BHRs vary significantly with pre-issue $B / M$, $L M 12, L E V I N V / A$, and ROA.

Table 4, Panel B examines the role of the discount rate effect, $X_{i}\left(\beta_{1}-\beta_{0}\right)$, in explaining long-run SEO underperformance. We mimic the unobservable expected return on sample firm $i$ in the non-issuing state by the return on a benchmark $j$, $E\left(R_{0 i} \mid D_{i}=0, X_{i}\right)=E\left(R_{0 j} \mid D_{j}=0, X_{j}\right)$. This leads to the discount rate effect being a function of differences in characteristics, $X_{0 i} \neq X_{0 j}$, and risk exposures, $\beta_{1} \neq \beta_{0}$. Column Beta diff reports coefficient differences for the two regressions in Panel A. SEOs have significantly lower $B / M$ and $R O A$ coefficients and a higher $M V$ coefficient than matching stocks. However, $d_{1}-d_{0}$ remains significant at $-18.2 \%{ }^{21}$ This shows that controlling for differences in risk, SEOs underperform their control stocks. The last four columns of Panel B report mean firm characteristics for SEOs (X SEO), matches ( $X$ matches), and their differences ( $X$ diff $)$ over the 3 -year post-issue period. ${ }^{22}$ SEOs are on average larger and more liquid than benchmark firms in the post-issue period with higher investment rates and book-to-market ratios, and lower gearing and profitability. With the exception of differences in post-issue $B / M$ ratios, this suggests lower SEO expected returns than for control stocks. The difference in $\log B / M$ is small $(0.024)$ and more than offset by a lower SEO $B / M$ coefficient (0.092) compared to control firms (0.189).

Based on the results in Table 4, new equity issuers have lower post-issue risk than matching stocks, consistent with the discount rate hypothesis. However, controlling for risk, SEOs continue to underperform benchmark stocks, which suggests that a discount rate effect alone does not explain low issuer returns. Next, we turn to the conditional estimator of SEO abnormal returns to test the underreaction explanation for SEO post-offering performance.

\footnotetext{
${ }^{20}$ Results in Table 4 use year- and industry-clustered standard errors and all variables are expressed as decimals rather than percentages in this and subsequent regressions.

${ }^{21}$ The $-18.2 \%$ estimate of SEO abnormal performance in Table 4, Panel B, is not comparable with the $-25.87 \%$ abnormal performance in Table 3, Panel A, as the former figure is the abnormal performance when the values of the risk characteristics, $X_{i}$, are set to zero.

${ }^{22}$ In calculating mean three-year post-issue characteristics we use all annual non-missing characteristics available for SEOs and control stocks. The table omits $p A B$, which relates to the pre-issue period. Table 5 below reports mean $p A B$ for SEOs, matching stocks, and their difference before the issue.
} 


\section{Predicting the Issue Decision and Conditional Estimates of the Issue Effect}

To obtain the conditional estimator of SEO abnormal returns in equation (9), we need $\lambda_{1 i}$ and $\lambda_{0 i}$ from the equity issue selection equation (4). We use Heckman's (1979) two-step procedure to estimate the equity issue decision and decompose SEO expected returns in the issue and non-issue states. The procedure uses a probit model to estimate the anticipated component of the issue decision, $Z_{i} \gamma$. To ensure the probit model uses the latest information available before the issue with no hindsight bias, we measure marketbased explanatory variables one month before the event. The accounting variables are for December at least six months before the issue. Accounting variables and LM12 are winsorised based on the CRSP population at $\pm 1 \%$. We group explanatory variables into five categories according to issue motives.

\section{Firm overvaluation}

Loughran and Ritter (1995) argue that stock mispricing encourages firms to issue overvalued equity. We use five variables to capture variation in firm mispricing. To measure pre-offering abnormal return performance we use $p A B$. A dummy variable, Hot, which equals 1 if the number of sample SEOs in the month before issue is above the median monthly number of sample SEOs over the previous 36 months and zero otherwise, captures waves of new equity issues as firms cluster offerings to exploit periodic stock mispricing (Loughran and Ritter, 2000). The variable Hot also captures Schultz's (2003) pseudo market timing hypothesis, which argues that equity issue waves coincide with peaks in stock market performance. Year dummies (Year dummies) and twelve industry dummies (Industry dummies) based on Kenneth French's industry definitions capture time and industry variation in mispricing. An indicator variable (Nasdaq) distinguishes Nasdaq from NYSE/AMEX listed firms.

\section{Growth options}

Carlson et al. (2006) and Li et al. (2009) argue that firms make SEOs to pursue profitable growth opportunities. We use $B / M$ and $I N V / A$ to measure growth options. Harjat and Garen (2003) report that $42 \%$ of IPOs make SEOs within four years of their IPOs. Younger and smaller firms require more investment capital at the start of their life cycle. We measure firm age (ln Age) as the difference between a firm's first CRSP listing date and the issue date, in $\log$ form. We use $\ln M V$ to measure firm size.

\section{Leverage and financial constraints}

The pecking order theory predicts that firms with insufficient internal funds to finance new investment resort to external financing. We use earnings growth $(E G), R O A$, and the inverse of the ratio of capital expenditures to the change in retained earnings plus depreciation and amortisation (IFC) to measure a firm's ability to generate internal funds. Myers (1977), Jensen (1986), and Stulz (1990) point out that high leverage limits a firm's ability to exploit new investment opportunities. We use $L E V$ to control for the higher propensity of high leverage firms to issue equity rather than debt to finance new projects. 


\section{Stock liquidity}

Eckbo et al. (2000) point out that an equity issue may improve a stock's liquidity and reduce the firm's expected returns. Butler et al. (2005) report that investment banks charge lower fees to firms with more liquid stock before the offering. Higher pre-SEO liquidity can ensure a higher uptake of new shares, lowering issue costs. To capture the effect of stock liquidity on the equity issue decision, we use $L M 12$.

\section{Information releases}

Korajczyk et al. $(1991,1992)$ predict that firms time equity issues to follow credible and significant information releases, which temporarily reduce information asymmetry between managers and investors. We create dummy variables (Issue month dummies) corresponding to calendar months. ${ }^{23}$ Given the prevalence of December fiscal year-ends in the USA, we expect issues to cluster around the earnings announcement months of March to June.

To estimate the probit model we require a sample of non-issuing firms. To select this sample, we use a procedure similar to Guo and Mech (2000). We randomly choose 60,000 security month-years (based on a random number generator and selection without replacement) from the monthly CRSP/Compustat merged files over 1970-2004. Excluding firms with insufficient CRSP/Compustat data leaves a sample of 21,101 nonissuing firm-year observations. Adding to these observations our size-B/M benchmark stocks gives a sample of 23,980 pseudo non-issuing events. Size-B/M matched stocks share pseudo non-event dates with the sample of SEOs.

The conditional returns of SEOs and matches, equation (7) and (8), are estimated jointly with the equity issue selection model, equation (4). This requires exclusion restrictions to ensure identification of the return equations, as missing or low quality instruments may result in collinearity between lambda and the discount rate effect $(\mathrm{Li}$ and Prabhala, 2008). The conditional returns equations include variables that previous studies find control for SEO risk and publicly available information predicting equity mispricing. Nasdaq, industry, year, hot and issue month dummies, firm age, the inverse of the firm's ability to generate internal funds, and earnings growth from the equity issue choice model (equation 4) form the instrument set. Previous studies provide no evidence that any of the dummy variables predict stock returns, which justifies excluding them from the return regression. ${ }^{24}$ A firm's ability to generate internal funds and earnings growth determine a firm's cash holding and its ability to finance new projects from internal as opposed to external sources.

Table 5, Panel A reports means, medians, and standard deviations of the variables that relate to the equity issue decision or control for risk for SEOs, matches, and the remaining CRSP stocks. The final four columns test for differences in characteristics

\footnotetext{
${ }^{23}$ To avoid multicollinearity, the model excludes one year, one industry and one issue month dummy.

${ }^{24}$ As we exclude IPO firms from our sample, age should play no role in predicting stock returns. Ex post, the internet bubble makes the 2001 year dummy a predictor of low returns in 2002. At the firm-level, however, the 2001 dummy is likely to be a much weaker predictor of returns and including (weakly) endogenous variables as instruments can improve estimation efficiency (Larcker and Rusticus, 2010).
} 


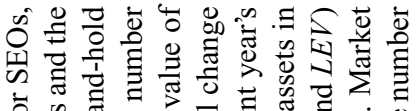

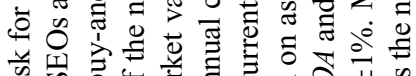

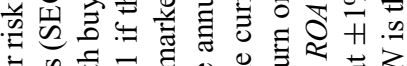
함대

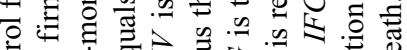

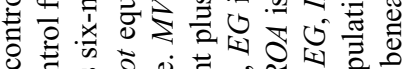

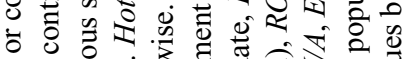

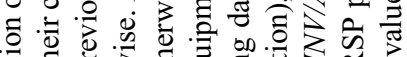

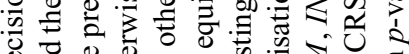

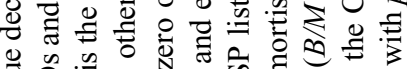
o 0 .

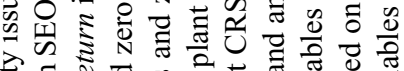

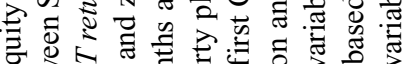

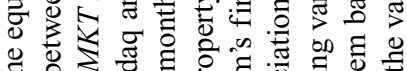

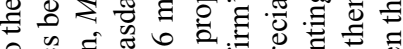

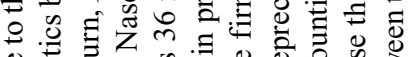
б

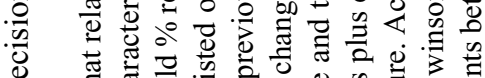
\& o o v क

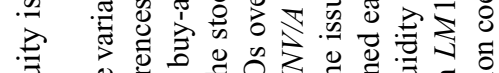
in $\frac{0}{2}$ ब

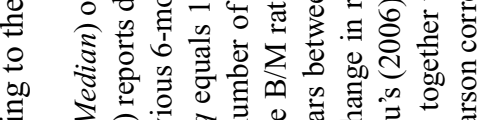

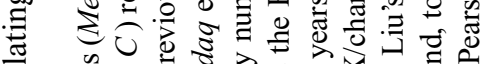

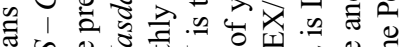

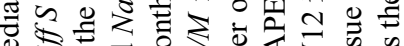

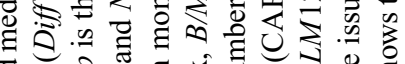

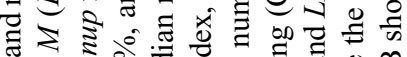

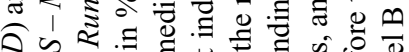

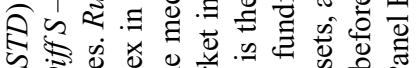

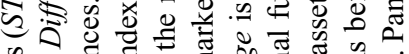

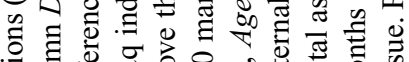

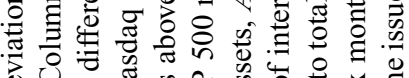

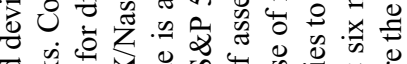

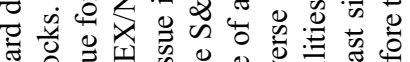

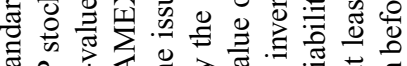

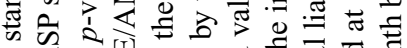

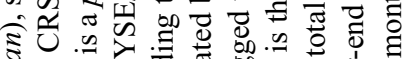

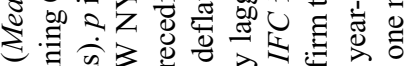

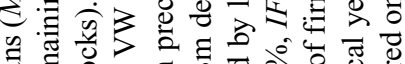

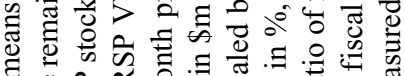

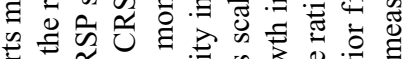

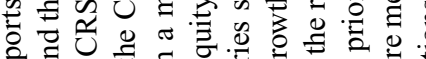

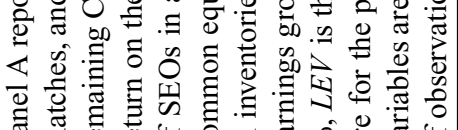

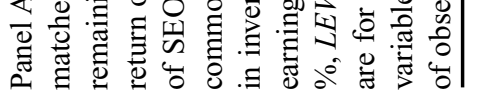

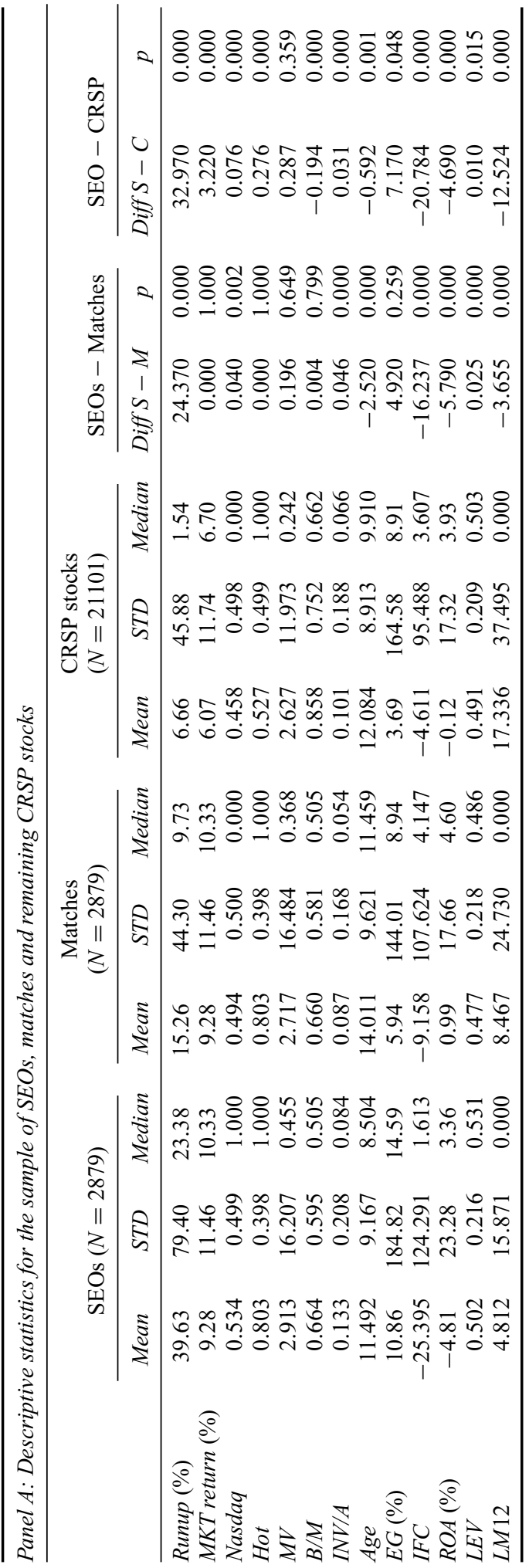




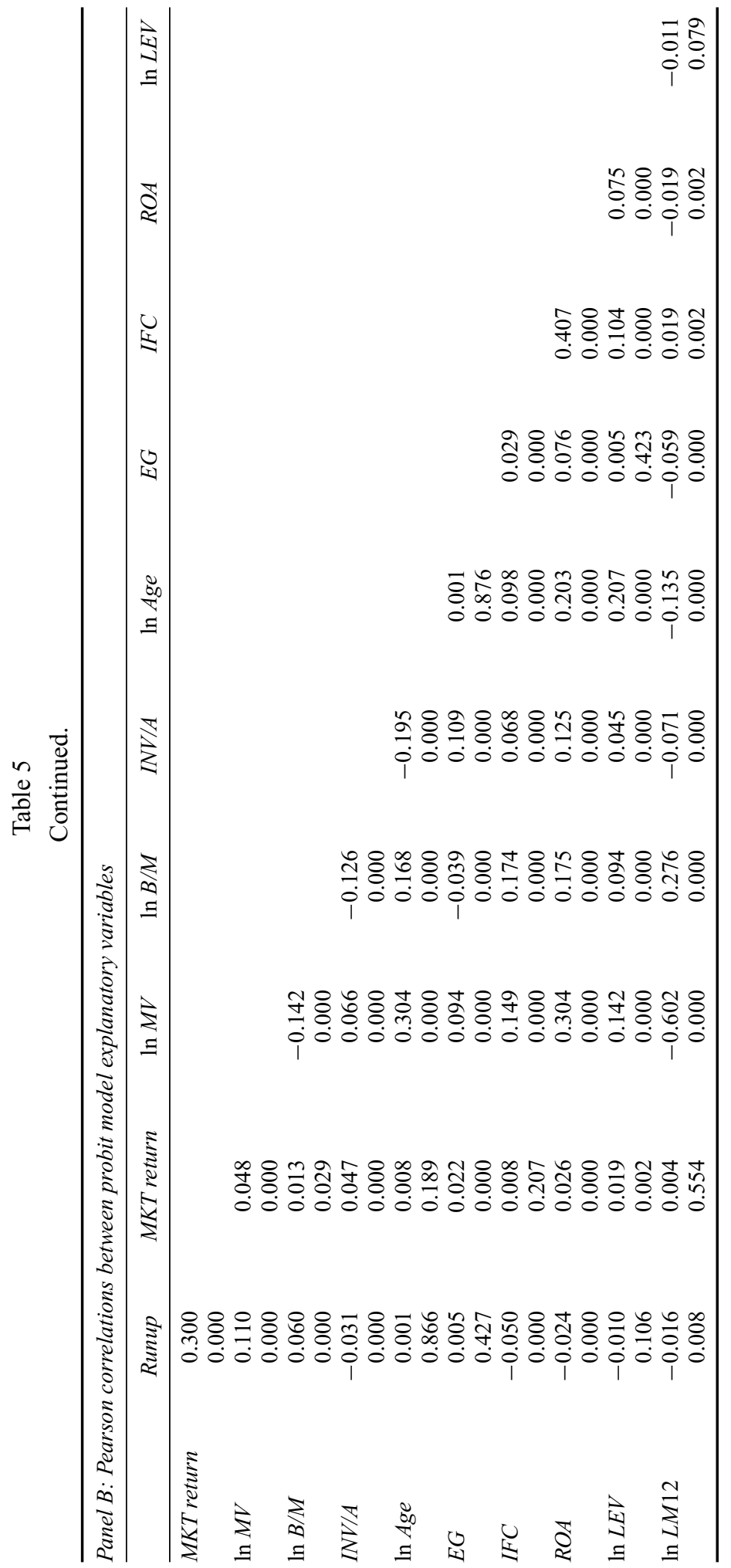


between SEOs and their matches and between SEOs and CRSP stocks. SEOs exhibit higher six-month pre-issue price run-up than matching firms (39.63\% vs. $15.26 \%)$ and the remaining CRSP stocks $(6.66 \%)$. They are also more likely to list on Nasdaq than are matches and the remaining CRSP stocks. Size-B/M matching before the issue is successful, but compared to their matches and the remaining CRSP stocks, SEOs have significantly higher investment rates, leverage, financial constraints and liquidity, and lower profitability. ${ }^{25}$ SEOs are younger than their matches and the remaining CRSP stocks, consistent with a higher reliance of younger firms on external capital. They also have significantly higher earnings growth compared to their matches and the remaining CRSP stocks and issues are more likely to cluster in periods of heavy issuing activity $(H o t=0.803$ vs. 0.527). Table 5, Panel B reports Pearson correlations between the variables. The magnitudes of the correlations are low, being 0.068 on average.

Table 6 reports the results of modelling the issue decision using a probit model applied to 26,859 firm-year observations and shows positive and significant coefficients on $p A B$, Nasdaq and a number of year, issue, and industry dummies (not reported). Periods of heavy (prior) issuing activity increase the likelihood of an equity offering and in our sample, larger companies are more likely to issue equity. High growth options, investment rates, and being early in the corporate life cycle, increase the propensity to issue. There is partial support for the financial constraints prediction, with a negative coefficient on $R O A$ but insignificant coefficients on $I F C$ and $E G$. High firm leverage and liquidity increase the probability of an equity issue. ${ }^{26}$

The marginal effects $(M E)$ indicate the importance of each variable in the issue decision. INV/A is the principal positive contributor to the issue decision $(7.27 \%)$, indicating that firms issue equity to pursue new investment. This is consistent with DeAngelo et al. (2010), Loughran and Ritter (1997), and Lyandres et al. (2008), who report high SEO investment rates before and after the offering. As in Huang and Ritter (2009) and DeAngelo et al. (2010), we find less profitable firms with insufficient internal funds are more likely to issue, with a unit decrease in $R O A$ contributing $6.25 \%$ to the probability of issue. These results are consistent with Myers and Majluf's (1984) rational equity issue model. Pre-issue abnormal performance, $p A B$, has a strong positive impact on the issue decision, which suggests managers are more likely to issue following recent price appreciation. Loughran and Ritter (2000, 362-363) argue that '[i]f there are time-varying misvaluations that firms capitalise on by taking some action (a supply response), there will be more events involving larger misvaluations in some periods than in others'. Hot has a positive influence on the issue probability, consistent with Loughran and Ritter's prediction.

Table 6, Panel B reports the predicted probability of an equity issue based on the estimates in Panel A for the sample of SEOs, matches, and the remaining CRSP stocks. A random non-issuing CRSP stock has an $8.92 \%$ probability of issuing equity in a given year. Matching firms have a higher issue probability (13.91\%), while SEOs have the highest predicted issue probability $(20.14 \%)$. Despite investors partly anticipating new

\footnotetext{
${ }^{25}$ SEOs improve stock liquidity after the issue, which explains the lower $L M 12$ value after the offering in Table 3.

${ }^{26}$ Unreported results show a significantly lower likelihood of equity issues in January and February. Straddling the (sample median) December fiscal year-end and the earnings announcement season (March), these months are likely to have higher levels of information asymmetry. Firms are also less likely to issue between July and October.
} 
Table 6

Probability of an equity issue

Panel A reports probit estimates (Estimate) of a model where the dependent variable is a dummy variable equal to 1 for firms making an SEO in a year and 0 otherwise. $p A B$ is the difference between the firm's and the market's prior six-month buy-and-hold return, Nasdaq equals 1 if the stock lists on Nasdaq and 0 otherwise. Hot equals 1 if the number of SEOs in a month preceding the issue is above the median monthly number of SEOs over the previous 36 months and zero otherwise. $M V$ is the market value of common equity in $\$ \mathrm{~m}$ deflated by the S\&P 500 market index, $B / M$ is the $\mathrm{B} / \mathrm{M}$ ratio, $I N V / A$ is the change in property plant and equipment plus the annual change in inventories scaled by lagged value of assets, Age is the number of years between the issue date and the firm's first CRSP listing date, $E G$ is the current year's earnings growth, $I F C$ measures the inverse of internal funding (CAPEX/change in retained earnings plus depreciation and amortisation), ROA is return on assets, $L E V$ is the ratio of firm total liabilities to total assets, and LM12 is Liu's (2006) liquidity measure. The model includes issue month, year and industry dummies using definitions from Kenneth French's webpage. Accounting variables $(B / M, I N V / A, E G, I F C, R O A$ and $L E V)$ are for the prior fiscal year-end allowing for a six month reporting gap and, together with $L M 12$, are winsorised based on the CRSP population at $\pm 1 \%$. Market variables ( $p A B, H o t, M V$, and $L M 12)$ are measured one month before the issue. Pred sign shows the predicted direction of the relation. $S E$ denotes standard errors, and $p$ the $p$-value based on $z$-statistics. Column $M E$ measures the percentage marginal effects for a unit change in the explanatory variables. Panel B shows the model mean predicted probability of equity issue for CRSP stocks, the sample of SEOs, and their matches.

Panel A: Estimates of the probability of equity issue

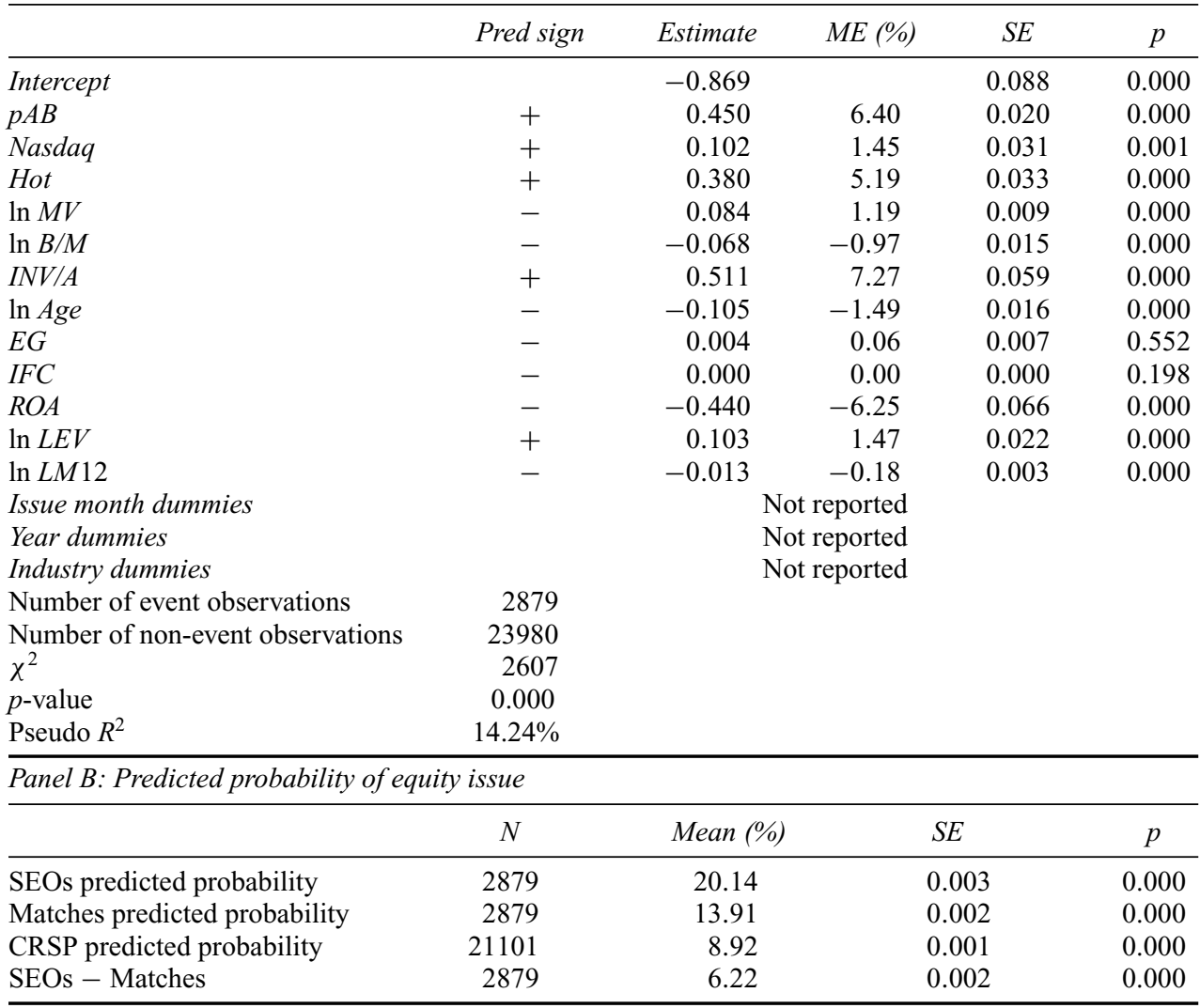


equity issues, the results suggest that SEOs surprise the market. Intuitively, even though investors rate certain stocks as being on average twice as likely to issue equity than an average (non-issuing) stock, not issuing is four times as likely even for these stocks. If investors are rational, stock prices should, on average, impound a fifth of the total issue effect before the offering with the issue announcement revealing the remaining $80 \%$ arising from managerial private information. Investors should discount this surprise component immediately and fully (see Figure 1a). If SEO stock prices do not react fully to managerial private information, there will be a negative relation between managerial information revealed at the announcement and post-issue stock returns.

Results in Table 6 underscore the importance of the unobservable private information in driving the issue decision. If investors behave less-than-rationally, our private information measure, lambda, will be a strong determinant of post-issue return. This suggests that tests of the underreaction hypothesis that relate publicly available information before the issue, e.g. abnormal price performance, rather than lambda to post-issue SEO returns have low power.

\subsection{The long-run performance of SEOs - conditional estimates}

The probit model results confirm that equity offerings are unexpected events and issue announcements convey significant information about managers' private information, $u_{d i}$, that is unobservable before the announcement. If the market rationally impounds this information, there should be a complete and unbiased price reaction at the issue announcement and post-offering stock returns should compensate for risk. If the market initially underreacts to the information and gradually corrects the overvaluation after the event, we should observe post-offering underperformance and post-issue correction should be larger for less anticipated SEOs.

Table 7, Panel A reports results for the conditional estimator of abnormal returns for SEOs and their control stocks, where the inverse Mills ratios $\left(\lambda_{0}, \lambda_{1}\right)$ proxy for unobservable private information. ${ }^{27}$ As predicted, the coefficient on $\lambda_{1}$ is significantly negative $(-0.165, p=0.028)$, indicating that greater private information leads to lower post-event performance. ${ }^{28} \mathrm{~A}$ one-standard deviation increase in lambda $(0.384)$ leads to a $6.33 \%$ lower SEO buy-and-hold return over the three years after the issue. SEO performance varies positively with pre-issue $B / M, M V$ (at $10 \%$ ), $L E V$, and $R O A$, and negatively with $I N V / A$ and $p A B$. There is no relation between private information and average returns for matching stocks, consistent with the random assignment of pseudoevent dates and lambda measuring only information revealed by managers at equity issue announcements. ${ }^{29}$ Similar to SEOs, long-run BHRs of matching stocks are positively related to pre-issue $B / M, L E V$, and $R O A$, and negatively related to $I N V / A$ and stock illiquidity (at 10\%).

Table 7, Panel B reports mean $\lambda_{1}$ and $\lambda_{0}$, and Pearson correlations between lambdas and the explanatory variables for SEOs and matching stocks. Mean lambda for SEOs is

\footnotetext{
${ }^{27}$ Including intercept terms captures any misspecification of the empirical model due to a failure to control for a delayed market reaction when comparing SEO and benchmark stock performance.

${ }^{28}$ Asymptotically consistent standard errors adjust for inclusion of first-stage predictors in the model.

${ }^{29}$ Table 9 reports further tests of lambda's validity in capturing only the SEO announcement effect, using the random non-issuer sample from the equity issue choice model in Table 5.
} 
Table 7

Regressions of buy-and-hold returns with private information adjustment

Panel A reports regression estimates (Estimate) for equations (7) and (8), where the dependent variable is the SEO's or the match's three-year buy-and-hold return. The explanatory variables are the B/M ratio $(B / M)$, total market capitalisation in \$m deflated by the S\&P 500 market index $(M V)$, Liu's (2006) liquidity measure ( $L M 12)$, leverage $(L E V)$, all in log form, investment-to-assets $(I N V / A)$, return on assets $(R O A)$ and pre-issue abnormal performance $(p A B) . M V, L M 12$ and $p A B$ are measured one month before the issue. $B / M, L E V, I N V / A$ and $R O A$ are for the prior fiscal year-end at least six months before the issue and, together with $L M 12$, are winsorised based on the CRSP population at $\pm 1 \% . \lambda_{0}, \lambda_{1}$ are the inverse Mills ratios from the equity issue model, proxying for managerial private information revealed by the issue announcement. $S E$ denotes asymptotically consistent standard errors, and $p$ gives the corresponding $p$-values. $N$ is the number of observations, $F$ and $P>F$ are the $F$-and corresponding $p$-values for model specification, $\operatorname{Adj} R^{2}$ is the adjusted R-square, rho is the correlation between the residuals in the issue selection equation (4) and unconditional expected post-issue returns for SEOs/matches (equations 1 and 2). Sigma is the standard error of residuals for the expected returns equations (1) and (2). Panel B reports mean lambda and Pearson correlation coefficients between lambda and other explanatory variables. Panel $\mathrm{C}$ shows the difference in coefficients between SEOs and control stocks (Beta diff). SE stands for standard errors and $p$ is a $p$-value for the significance of the differences.

Panel A: Conditional issue effect

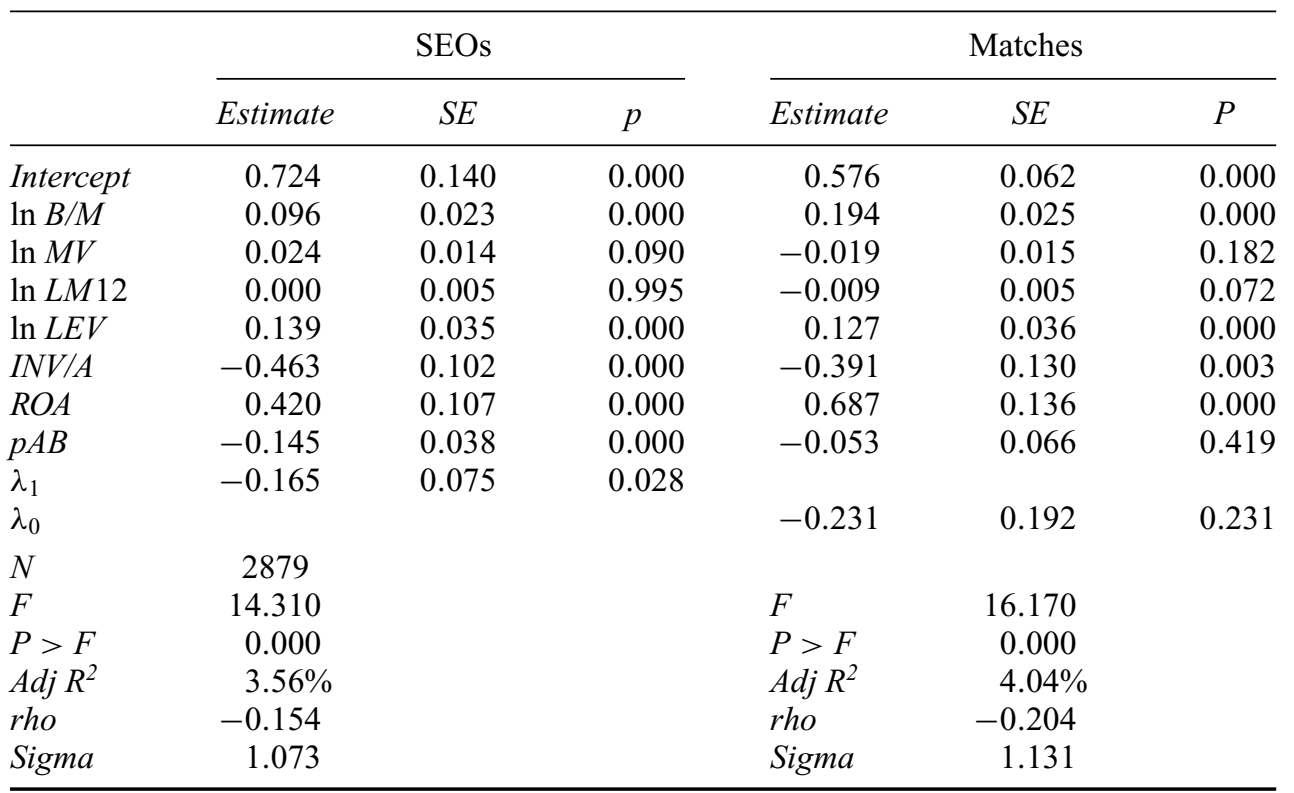

Panel B: Mean lambda and Pearson correlations between lambda and explanatory variables

\begin{tabular}{lrrrrrrrr}
\hline \multicolumn{2}{c}{ Mean lambda } & $\ln B / M$ & \multicolumn{1}{c}{$\ln M V$} & $\operatorname{In} L M 12$ & $\ln L E V$ & $I N V / A$ & $R O A$ & \multicolumn{1}{c}{$p A B$} \\
\hline$\lambda_{1}$ & 1.485 & 0.125 & -0.149 & 0.331 & 0.038 & -0.135 & 0.302 & -0.523 \\
$p$ & 0.000 & 0.000 & 0.000 & 0.000 & 0.042 & 0.000 & 0.000 & 0.000 \\
$\lambda_{0}$ & -0.252 & 0.152 & -0.187 & 0.333 & -0.053 & -0.119 & 0.284 & -0.572 \\
$p$ & 0.000 & 0.000 & 0.000 & 0.000 & 0.004 & 0.000 & 0.000 & 0.000 \\
\hline
\end{tabular}


Table 7

Continued.

Panel C: Differences in regression coefficients

\begin{tabular}{lcrrrrrrr}
\hline & Intercept & $\ln B / M$ & $\ln M V$ & $\ln L M 12$ & $\ln L E V$ & $I N V / A$ & \multicolumn{1}{c}{$R O A$} & \multicolumn{1}{c}{$p A B$} \\
\hline Beta diff & 0.149 & -0.098 & 0.043 & 0.009 & 0.011 & -0.072 & -0.267 & -0.092 \\
$S E$ & 0.153 & 0.034 & 0.020 & 0.007 & 0.050 & 0.165 & 0.173 & 0.076 \\
$p$ & 0.332 & 0.004 & 0.033 & 0.199 & 0.820 & 0.662 & 0.123 & 0.228 \\
\hline
\end{tabular}

significantly higher than for matching stocks (1.485 vs. -0.252$)$, which confirms the amount of private information revealed by managers at the SEO announcement. ${ }^{30}$ All correlations are significant, with the average absolute correlation between lambda and the explanatory variables being 0.229 (0.243) for SEOs (matches).

Table 7, Panel C reports coefficient differences between the two Panel A regressions and tests their significance. Including lambda in the conditional return regressions, we find no indications of SEO underperformance, with the intercept difference being indistinguishable from zero. Coefficient differences between regressions of SEOs and matches show similar significance levels to Table 4, Panel C, except for $R O A$, which is indistinguishable from zero. This suggests unconditional estimates in Table 4 understate lower SEO post-issue risk exposure compared to benchmark stocks due to omitting lambda, i.e. $X_{i}\left(\hat{\beta}_{1}^{\prime}-\hat{\beta}_{0}^{\prime}\right)<X_{i}\left(\hat{\beta}_{1}-\hat{\beta}_{0}\right)$.

From Table 7, we can obtain an unbiased and consistent estimate of issuer underperformance due to investor underreaction. From equation (9), we estimate SEO underperformance as the difference between the products of the covariance and lambda estimates for SEOs and matching stocks, $\hat{\sigma}_{u_{d} u_{1}} \hat{\lambda}_{1 i}-\hat{\sigma}_{u_{d} u_{0}} \hat{\lambda}_{0 i}$, plus the difference between SEO and matching stock intercepts. ${ }^{31}$ This gives an SEO underperformance estimate due to investor underreaction over the three years after the issue of $-15.43 \%$, which accounts for $59 \%$ of the $-25.87 \%$ abnormal performance in Table 3. Lower SEO risk exposure after the issue leads to abnormal performance of $-10.44 \%$ relative to size-B/M control stocks, which confirms that investor delay in impounding the information surprise at the issue announcement is the main generator of SEO abnormal performance. ${ }^{32}$

Overall, the results in Table 7 confirm the hypothesis that a delayed reaction to managers' private information revealed by the equity issue leads to negative post-issue abnormal performance. After the offering, there is a negative relation between SEO stock returns and managers' private information but there is no relation between private information and average returns for matching stocks.

\footnotetext{
${ }^{30}$ The lambda coefficients in Table 7, Panel A adjust for higher SEO than control firm mean lambda (1.485 vs. -0.252$)$, which explains higher point estimate magnitudes for $\lambda_{0 i}$ $(-0.231)$ than $\lambda_{1 i}(-0.165)$.

${ }^{31}$ The intercepts capture potential misspecification of the empirical model in Table 6 and their difference has zero expectation.

${ }^{32}$ A sensitivity analysis shows that a $10 \%$ higher lambda coefficient increases the share of SEO underperformance attributable to investor underreaction from the current level of 59\% to $69 \%$. A lambda coefficient of -0.235 means investor irrationality accounts for nearly $100 \%$ of total SEO underperformance and is the upper bound for a 'reasonable' lambda estimate.
} 


\subsection{Sensitivity analysis}

Table 7 shows a significant negative relation between SEO long-run returns and managers' private information revealed by the announcement, proxied by $\lambda_{1}$. This suggests that investors only partially discount the information surprise at the issue announcement and this underreaction corrects over a post-offering period. Next, we examine the sensitivity of the results to pre-issue abnormal return performance, SEO attrition before the end of the holding period, delisting returns, and periods of high equity issue volume.

If higher investor optimism about firm prospects leads to greater stock overvaluation, we should find greater underperformance for SEOs preceded by higher stock price performance. Table 8, Panel A tests this prediction, where we report regression results for SEOs with high and low pre-issue abnormal performance. ${ }^{33}$ While $\lambda_{1}$ is insignificant for low $p A B$ SEOs, high $p A B$ SEOs have a significant $\lambda_{1}$ coefficient of -0.194 ; a onestandard deviation increase in lambda (0.47) for high $p A B$ SEOs leads to a $9.13 \%$ lower buy-and-hold return over the three years after the issue. These results support the prediction that investors underreact more to SEO announcements preceded by a strong price run-up.

Shumway (1997) and Shumway and Warther (1999) address the impact of omitting delisting returns on stock return calculations. Both studies find that including delisting returns can significantly alter inferences on many anomalies. For example, Shumway and Warther (1999) find that correcting for delisting bias eliminates the size effect for Nasdaq stocks. Beaver et al. (2007) confirm that including delisting returns increases the average return difference between extreme decile portfolios partitioned on earnings, cash flows, and $\mathrm{B} / \mathrm{M}$ ratio. To ensure omitting delisting returns does not affect our results, we repeat our analysis using CRSP delisting returns. Where a delisting return is missing, we assume a return of -1 for delisting due to liquidation (CRSP codes 400-490), -0.33 for performance related delisting (500 and 520-584), and zero otherwise. Using delisting returns has virtually no effect on coefficient estimates indicating that our findings are robust to delisting bias (results not tabulated). This is consistent with Shumway (1997) who finds a less than 1\% per year difference in three-year underperformance estimates for NYSE/AMEX listed IPOs after adjusting for delisting bias.

SEO attrition before the end of the three-year holding period may affect our results. For example, low buy-and-hold returns over the 36-month post-issue period can result from delayed market reaction or from firm attrition due to bankruptcy or acquisition. If the delisting probability depends on $\lambda_{1}$, low estimated returns may be due to intervening events rather than to a delayed market reaction to an SEO announcement. There are 2,419 SEOs with 36 months of returns. For 455 SEOs the CRSP files identify the reason for delisting before the end of the three-year holding period: 285 delist due to mergers/acquisitions, 157 are delisted by their exchange (NYSE/AMEX/Nasdaq), and 13 delist due to an exchange of shares for another type of asset. While it involves a hindsight bias, we repeat our analysis using only SEOs that survive to the end of the three-year holding period (results not tabulated). The results are qualitatively similar to

\footnotetext{
${ }^{33}$ We estimate subsample cross-sectional regressions jointly with the equity issue model (equation 4) to ensure consistent standard error estimates. The results are indistinguishable from regression estimates that use the original lambda estimates from Table 6. For example, the percentage difference in SEO lambda coefficients for the two approaches is $3.87 \%$ for high $p A B$ in Table 8, Panel A.
} 
Table 8

Sensitivity analysis

Panel A reports regression estimates (Estimate) for SEOs split into High and Low groups based on pre-issue abnormal performance $(p A B)$. The dependent variable is the SEO's three-year buy-and-hold return. The explanatory variables are the $\mathrm{B} / \mathrm{M}$ ratio $(B / M)$, total market capitalisation in $\$ \mathrm{~m}$ deflated by the S\&P 500 market index (MV), Liu's (2006) liquidity measure (LM12), leverage (LEV), all in $\log$ form, investment-to-assets $(I N V / A)$, return on assets $(R O A)$ and pre-issue abnormal performance (pAB). MV, LM 12 and $p A B$ are measured one month before the issue. $B / M, L E V, R O A$ and $I N V / A$ are for the prior fiscal year-end at least six months before the issue and, together with $L M 12$, are winsorised based on the CRSP population at $\pm 1 \% . \lambda_{1}$ is the inverse Mills ratio from the equity issue model, proxying for managerial private information. $S E$ denotes asymptotically consistent standard errors and $p$ is the $p$-value. $N$ is the number of observations, $F$ and $P>F$ are the $F$-and corresponding $p$-values for model specification, $\operatorname{Adj} R^{2}$ is the adjusted R-square, rho is the correlation between residuals in the issue selection equation (4) and unconditional expected post-issue returns for SEOs. Sigma is the standard error of the residuals for unconditional SEO expected returns. Panel B shows regression estimates for SEOs made during high ( $\mathrm{Hot}$ ) and low (Cold) issue volume months, where an issue month is Hot (Cold) if the number of sample SEOs in a month preceding the issue is above (below) the median monthly number of sample SEOs over the previous 36 months.

Panel A: Grouping SEOs by pre-issue abnormal performance

\begin{tabular}{|c|c|c|c|c|c|c|}
\hline & \multicolumn{3}{|c|}{ High $p A B$} & \multicolumn{3}{|c|}{ Low $p A B$} \\
\hline & Estimate & $S E$ & $p$ & Estimate & $S E$ & $p$ \\
\hline Intercept & 0.874 & 0.194 & 0.000 & 0.640 & 0.215 & 0.003 \\
\hline $\ln B / M$ & 0.104 & 0.029 & 0.000 & 0.069 & 0.037 & 0.060 \\
\hline $\ln M V$ & 0.016 & 0.020 & 0.416 & 0.011 & 0.022 & 0.633 \\
\hline $\ln L M 12$ & 0.001 & 0.006 & 0.850 & -0.006 & 0.008 & 0.417 \\
\hline $\ln L E V$ & 0.148 & 0.042 & 0.000 & 0.124 & 0.058 & 0.031 \\
\hline$I N V / A$ & -0.529 & 0.130 & 0.000 & -0.407 & 0.154 & 0.009 \\
\hline$R O A$ & 0.498 & 0.129 & 0.000 & 0.272 & 0.167 & 0.103 \\
\hline$p A B$ & -0.209 & 0.054 & 0.000 & 0.460 & 0.192 & 0.017 \\
\hline$\lambda_{1}$ & -0.194 & 0.089 & 0.030 & -0.124 & 0.105 & 0.236 \\
\hline$N$ & 1439 & & & $N$ & 1440 & \\
\hline$F$ & 11.030 & & & $F$ & 5.700 & \\
\hline$P>F$ & 0.000 & & & $P>F$ & 0.000 & \\
\hline $\operatorname{Adj} R^{2}$ & $5.28 \%$ & & & $\operatorname{Adj} R^{2}$ & $2.54 \%$ & \\
\hline rho & -0.206 & & & rho & -0.105 & \\
\hline Sigma & 0.940 & & & Sigma & 1.187 & \\
\hline Mean $p A B$ & $70.59 \%$ & & & Mean $p A B$ & $-10.01 \%$ & \\
\hline Median $p A B$ & $45.85 \%$ & & & Median $p A B$ & $-4.98 \%$ & \\
\hline
\end{tabular}

Panel B: SEOs in hot and cold issuing periods

\begin{tabular}{lcccccccc}
\hline & \multicolumn{3}{c}{ Hot } & & \multicolumn{3}{c}{ Cold } \\
\cline { 2 - 3 } & Estimate & $S E$ & $p$ & & Estimate & SE & $p$ \\
\hline Intercept & 1.096 & 0.178 & 0.000 & & 1.356 & 0.475 & 0.005 \\
$\ln B / M$ & 0.118 & 0.024 & 0.000 & & 0.076 & & 0.073 & 0.303 \\
$\ln M V$ & 0.025 & 0.015 & 0.092 & & -0.034 & & 0.042 & 0.416 \\
\hline
\end{tabular}


Table 8

Continued.

\begin{tabular}{lccccccc}
\hline & \multicolumn{3}{c}{ Hot } & & & \multicolumn{2}{c}{ Cold } \\
\cline { 2 - 3 } & Estimate & SE & $p$ & & Estimate & SE & $p$ \\
\hline $\ln L M 12$ & 0.006 & 0.005 & 0.258 & & -0.008 & 0.013 & 0.547 \\
$\ln L E V$ & 0.125 & 0.036 & 0.001 & & 0.152 & 0.102 & 0.135 \\
$I N V / A$ & -0.495 & 0.110 & 0.000 & & -0.870 & 0.297 & 0.004 \\
$R O A$ & 0.491 & 0.116 & 0.000 & & 0.722 & 0.329 & 0.029 \\
$p A B$ & -0.221 & 0.044 & 0.000 & & -0.175 & 0.111 & 0.116 \\
$\lambda_{1}$ & -0.403 & 0.101 & 0.000 & & -0.440 & 0.433 & 0.310 \\
$N$ & 2311 & & & & & 568 & \\
$F$ & 14.970 & & & & $F$ & 2.480 & \\
$P>F$ & 0.000 & & & & $P>F$ & 0.012 & \\
Adj $R^{2}$ & $4.61 \%$ & & & & Adj $R^{2}$ & $2.06 \%$ & \\
rho & -0.391 & & & rho & -0.310 & \\
Sigma & 1.032 & & & Sigma & 1.421 & \\
\hline
\end{tabular}

those in Table 7, Panel A. Coefficient signs and significance are similar for the sample without return attrition.

Loughran and Ritter (2000) report greater underperformance following periods of heavy issuing activity. If time-varying investor optimism (sentiment) about firm prospects leads to mispricing of a group of stocks and consequent equity issue waves, greater underreaction to managerial private information can lead to greater underperformance following periods of high issue volume. Table 8, Panel B reports conditional estimates of the issue effect in hot and cold issuing periods. ${ }^{34}$ There are 2,311 equity offerings in hot and 568 in cold issue periods. SEOs in hot periods have a $\lambda_{1}$ coefficient of -0.403 , while $\lambda_{1}$ is indistinguishable from zero in cold periods. The downward trend in $\lambda_{1}$ in moving from low to high issue volume months and relative to the pooled sample in Table 7, Panel A is consistent with investors underreacting more to SEO announcements made during hot issue periods.

\subsection{Empirical model specification}

Using lambda to proxy for managers' private information inevitably leads to the joint hypothesis of underreaction and the validity of the model used to estimate lambda. Misspecification of equation (4) may result in lambda picking up publicly available information affecting a wide cross-section of returns, in addition to SEO-specific managerial private information. We test the specification of lambda by relating it to three-year buy-and-hold returns of random non-issuer samples from the equity issue choice model in Table 6 (excluding size-B/M benchmark stocks). Table 9 shows results for 20,783 non-issuing stocks with non-missing returns after the pseudo event date and three random subsamples of 5,000 stocks each. There is no association between lambda

\footnotetext{
${ }^{34}$ In calculating hot issue periods for 1970-1972, we append our initial SEO sample with annual data from Eckbo et al. (2000). We convert the annual to monthly estimates assuming equal monthly issue frequencies.
} 
Table 9

Sensitivity analysis: empirical model specification

This table reports regression estimates (Estimate) for a random sample of non-issuing CRSP stocks from the equity issue decision in Table 6 and three random subsamples of 5,000 stocks. There are 20,783 non-issuing stocks (excluding size-B/M benchmark stocks) with non-missing returns. The dependent variable is the non-issuer's three-year buy-and-hold return. The explanatory variables are the $\mathrm{B} / \mathrm{M}$ ratio $(B / M)$, total market capitalisation in \$m deflated by the S\&P 500 market index $(M V)$, Liu's (2006) liquidity measure $(L M 12)$, leverage $(L E V)$, all in log form, investment-to-assets $(I N V / A)$, return on assets $(R O A)$ and pre-issue abnormal performance $(p A B) . M V, L M 12$ and $p A B$ are measured one month before the issue. $B / M, L E V, R O A$ and $I N V / A$ are for the prior fiscal year-end at least six months before the issue and, together with $L M 12$, are winsorised based on the CRSP population at $\pm 1 \% . \lambda_{0}$ is the inverse Mills ratio from the equity issue model, proxying for managerial private information. $p$ is the $p$-value based on asymptotically consistent standard errors. $N$ is the number of observations, $F$ and $P>F$ are the $F$ - and corresponding $p$-values for model specification, $A d j R^{2}$ is the adjusted R-square, $r h o$ is the correlation between residuals in the issue selection equation (4) and unconditional expected post-event returns for non-issuing stocks. Sigma is the standard error of residuals for unconditional expected returns.

\begin{tabular}{|c|c|c|c|c|c|c|c|c|}
\hline & \multicolumn{2}{|c|}{ All non-issuers } & \multicolumn{2}{|c|}{$\begin{array}{c}\text { Random sample } \\
1\end{array}$} & \multicolumn{2}{|c|}{$\begin{array}{l}\text { Random sample } \\
2\end{array}$} & \multicolumn{2}{|c|}{$\begin{array}{c}\text { Random sample } \\
3\end{array}$} \\
\hline & Estimate & $p$ & Estimate & $p$ & Estimate & $p$ & Estimate & $p$ \\
\hline Intercept & 0.646 & 0.000 & 0.610 & 0.000 & 0.633 & 0.000 & 0.604 & 0.000 \\
\hline $\ln B / M$ & 0.148 & 0.000 & 0.125 & 0.000 & 0.172 & 0.000 & 0.174 & 0.000 \\
\hline $\ln M V$ & -0.008 & 0.275 & 0.015 & 0.013 & 0.001 & 0.915 & -0.006 & 0.389 \\
\hline $\ln L M 12$ & 0.000 & 0.943 & 0.006 & 0.003 & -0.002 & 0.482 & 0.000 & 0.924 \\
\hline $\ln L E V$ & 0.066 & 0.001 & 0.000 & 0.993 & 0.102 & 0.000 & -0.003 & 0.864 \\
\hline$I N V / A$ & -0.241 & 0.000 & -0.295 & 0.000 & -0.052 & 0.375 & -0.289 & 0.000 \\
\hline$R O A$ & 0.289 & 0.000 & 0.436 & 0.000 & 0.400 & 0.000 & 0.314 & 0.000 \\
\hline$p A B$ & -0.013 & 0.685 & -0.017 & 0.529 & -0.038 & 0.199 & -0.049 & 0.095 \\
\hline$\lambda_{0}$ & 0.120 & 0.269 & 0.132 & 0.135 & -0.027 & 0.783 & 0.072 & 0.460 \\
\hline$N$ & 20783 & & 5000 & & 5000 & & 5000 & \\
\hline$F$ & 29.400 & & 10.470 & & 10.060 & & 10.470 & \\
\hline$P>F$ & 0.000 & & 0.000 & & 0.000 & & 0.000 & \\
\hline $\operatorname{Adj} R^{2}$ & $1.08 \%$ & & $1.49 \%$ & & $1.43 \%$ & & $1.49 \%$ & \\
\hline rho & 0.073 & & 0.099 & & -0.018 & & 0.049 & \\
\hline Sigma & 1.630 & & 1.328 & & 1.485 & & 1.467 & \\
\hline
\end{tabular}

and non-issuer stock returns. This suggests proper specification of the empirical model in equation (4) and supports our main conclusions.

Results for non-issuing stocks in Table 7, Panel A and Table 9 allow us to address the classic problem of the SEO and IPO underperformance literature that a factor explaining SEO underperformance can proxy for stock misvaluation or risk (Brav and Heaton, 2002). For example, Lyandres et al. (2008, p. 2830) acknowledge that sentiment can also explain the relation between their investment factor and issuer returns: 'Following Fama and French $(1993,1996)$, we interpret the investment factor as a common factor of stock returns.... We do not take a stance on the risk interpretation of the investment factor.... General equilibrium models with behavioural biases (e.g., Barberis et al., 2001), however, also can motivate the investment factor. Moreover, investor sentiment 
can presumably affect investment policy through shareholders' discount rates (e.g., Polk and Sapienza, 2009).' Our results support only the behavioural explanation for the relation between lambda and post-issue SEO returns.

\section{How Long Is the Delayed Market Reaction?}

The previous analysis uses three-year buy-and-hold returns as the dependent variable. To estimate the length of the (delayed) reaction to SEO announcements, we re-run the regressions varying the buy-and-hold return period and measuring the relation with lambda.

To gauge how quickly the market discounts the announcement date information, Table 10 reports lambda coefficients from regressions where we increase the start date for measuring post-issue buy-and-hold returns by one month but fix the end of the holding period at month 36 after the offering. If stock price fully impounds $u_{d i}$ by month $\tau$ after the issue, we should find no relation between lambda and buy-and-hold returns over months $\tau$ to $36 .{ }^{35}$ The results suggest that investors impound the negative announcement date information into stock price over a shorter period after the offering than the five-year period that Loughran and Ritter (1995) suggest. There is a significant negative relation between lambda and post-offering long-run returns for SEOs over the course of 16 months after the issue (at 5.8\% significance). This is consistent with the period of negative SEO returns in Table 3, Panel B. Following the 16-month period after the issue, low risk explains low SEO returns. ${ }^{36}$ A sixteen month period to discount managerial information is consistent with the length of irrational investor behaviour around other corporate events.

\section{Conclusions}

Loughran and Ritter (1995) and Spiess and Affleck-Graves (1995) argue that managers act on their private information about stock overvaluation in making SEOs, but investors underreact to the issue announcement and stock mispricing persists at the issue date. The market revalues the stock over an extended period following the offering, leading to negative post-offering abnormal returns. We use the inverse Mills ratio (lambda) from a probit model of the issue decision based on publicly available information, to proxy for managers' private information revealed by the issue announcement. Less anticipated SEO announcements have higher surprise components, implying greater stock overvaluation and giving higher lambdas. To test the underreaction hypothesis, we relate lambda to long-run post-issue returns.

This study documents average SEO abnormal returns of $-25.87 \%$ relative to size- $\mathrm{B} / \mathrm{M}$ non-issuing stocks over the three years after the issue for a sample of 2,879 equity issues in the US over 1970-2004. SEO underperformance decomposes into a $-15.43 \%$ abnormal

\footnotetext{
${ }^{35}$ To ensure consistent standard errors, we estimate the probit and the cross-sectional regressions each event month.

${ }^{36}$ The evidence in Ang and Zhang (2004) that the power of calendar time Fama-French factor regressions decreases sharply with the event horizon coupled with our evidence that SEO underperformance corrects within 16 months after the issue underlines doubts about the power of tests that use calendar time factor regressions with a five-year holding period to detect SEO abnormal performance.
} 
Table 10

The speed of correction to private information

This table reports lambda estimates (Lambda estimate), where the start date for measuring post-issue SEO buy-and-hold returns increases by one month, holding the period end fixed at month 36 after the issue. Lambda is the inverse Mills ratio, based on the equity issue model in Table 6, and proxies for the magnitude of pre-event information asymmetry. The dependent variable is the SEO's three-year buyand-hold return. The explanatory variables (not reported here) are the $\mathrm{B} / \mathrm{M}$ ratio $(B / M)$, total market capitalisation in \$m deflated by the S\&P 500 market index $(M V)$, Liu's (2006) liquidity measure (LM12), leverage $(L E V)$, all in log form, investment-to-assets $(I N V / A)$, return on assets $(R O A)$ and pre-issue abnormal performance $(p A B) . M V, L M 12$ and $p A B$ are for one month before the event date. $B / M, L E V, R O A$ and $I N V / A$ are for the prior fiscal year-end at least six months before the offering date and, together with $L M 12$, are winsorised based on the CRSP population at $\pm 1 \%$. Period shows the buy-and-hold returns holding period and $N$ is the number of observations. $S E$ and $p$ are the asymptotic standard errors and associated $p$-values.

\begin{tabular}{|c|c|c|c|c|}
\hline Period & $N$ & Lambda estimate & $S E$ & $p$ \\
\hline $0-36$ & 2879 & -0.165 & 0.075 & 0.028 \\
\hline $1-36$ & 2834 & -0.199 & 0.074 & 0.008 \\
\hline $2-36$ & 2822 & -0.190 & 0.073 & 0.010 \\
\hline $3-36$ & 2808 & -0.207 & 0.075 & 0.006 \\
\hline $4-36$ & 2790 & -0.225 & 0.075 & 0.003 \\
\hline $5-36$ & 2783 & -0.241 & 0.074 & 0.001 \\
\hline $6-36$ & 2774 & -0.206 & 0.068 & 0.002 \\
\hline $7-36$ & 2755 & -0.198 & 0.069 & 0.004 \\
\hline $8-36$ & 2729 & -0.183 & 0.065 & 0.005 \\
\hline $9-36$ & 2717 & -0.187 & 0.067 & 0.005 \\
\hline $10-36$ & 2701 & -0.184 & 0.070 & 0.008 \\
\hline $11-36$ & 2679 & -0.186 & 0.070 & 0.008 \\
\hline $12-36$ & 2661 & -0.156 & 0.069 & 0.024 \\
\hline $13-36$ & 2635 & -0.153 & 0.067 & 0.022 \\
\hline $14-36$ & 2630 & -0.152 & 0.063 & 0.016 \\
\hline $15-36$ & 2615 & -0.149 & 0.064 & 0.020 \\
\hline $16-36$ & 2600 & -0.115 & 0.061 & 0.058 \\
\hline $17-36$ & 2584 & -0.095 & 0.063 & 0.128 \\
\hline $18-36$ & 2570 & -0.062 & 0.062 & 0.319 \\
\hline $19-36$ & 2542 & -0.029 & 0.059 & 0.621 \\
\hline $20-36$ & 2534 & -0.013 & 0.061 & 0.835 \\
\hline $21-36$ & 2515 & -0.013 & 0.057 & 0.823 \\
\hline $22-36$ & 2495 & -0.026 & 0.055 & 0.639 \\
\hline $23-36$ & 2482 & -0.020 & 0.055 & 0.712 \\
\hline $24-36$ & 2466 & -0.025 & 0.051 & 0.626 \\
\hline $25-36$ & 2453 & -0.019 & 0.050 & 0.709 \\
\hline $26-36$ & 2431 & -0.031 & 0.045 & 0.488 \\
\hline $27-36$ & 2418 & -0.033 & 0.043 & 0.441 \\
\hline $28-36$ & 2400 & -0.025 & 0.038 & 0.513 \\
\hline $29-36$ & 2385 & -0.026 & 0.037 & 0.480 \\
\hline $30-36$ & 2369 & -0.029 & 0.037 & 0.432 \\
\hline $31-36$ & 2356 & -0.028 & 0.035 & 0.415 \\
\hline $32-36$ & 2345 & -0.035 & 0.025 & 0.155 \\
\hline
\end{tabular}


Table 10

Continued.

\begin{tabular}{lcccc}
\hline Period & $N$ & Lambda estimate & $S E$ & $p$ \\
\hline $33-36$ & 2330 & -0.011 & 0.021 & 0.598 \\
$34-36$ & 2324 & -0.005 & 0.017 & 0.766 \\
$35-36$ & 2310 & -0.020 & 0.013 & 0.147 \\
\hline
\end{tabular}

performance due to investor underreaction to managers' private information revealed by the issue announcement and a $-10.44 \%$ return performance due to lower SEO risk exposure after the issue. After the equity offering, issuers are larger, more liquid, with higher investment rates and book-to-market ratios, and lower gearing and profitability than their size and $\mathrm{B} / \mathrm{M}$ peers. Investor underreaction to the announcement corrects within the first 16 months after the offering. Lower risk explains SEO performance after that point.

Our evidence confirms that a delayed reaction to information in the issue announcement is the main generator of SEO abnormal performance. The result is robust to controlling for the effects of pre-issue abnormal performance, SEO return attrition before the end of the holding period, delisting returns, periods of high equity issue volume, and tests for model misspecification.

The study's research framework is applicable to any corporate event where the endogenous decision to participate depends on managers' private information and investors do not fully react to the announcement date signal. Event studies that examine long horizon effects of stock repurchases and stock financed acquisitions are two examples where the framework can lead to insights. We encourage more European evidence on the length and magnitude of issuer underperformance due to less-thanrational investor behaviour. Institutional and regulatory differences make Europecentered research an ideal setting for out-of-sample tests.

\section{References}

Amihud, Y., 'Illiquidity and stock returns: cross-section and time-series effects', Journal of Financial Markets, Vol. 5, 2002, pp. 31-56.

Ang, J. and Zhang, S., 'An evaluation of testing procedures for long horizon event studies', Review of Quantitative Finance and Accounting, Vol. 23, 2004, pp. 251-74.

Baker, M. and Wurgler, J., 'The equity share in new issues and aggregate stock returns', Journal of Finance, Vol. 55, 2000, pp. 2219-57.

Barber, B. M. and Lyon, J. D., 'Detecting long-run abnormal stock returns: the empirical power and specification of test-statistics', Journal of Financial Economics, Vol. 43, 1997, pp. 341-72.

Barberis, N., Huang, M. and Santos, T., 'Prospect theory and asset prices', Quarterly Journal of Economics, Vol. 116, 2001, pp. 1-53.

Bayless, M., and Chaplinsky, S., 'Is there a window of opportunity for seasoned equity issuance?' Journal of Finance, Vol. 51, 1996, pp. 253-78.

Beaver, W., McNichols, M. and Price, R., 'Delisting returns and their effect on accounting-based market anomalies', Journal of Accounting and Economics, Vol. 43, 2007, pp. 341-68.

Bernard, V. and Thomas, J., 'Post-earnings-announcement drift: delayed price response or risk premium?', Journal of Accounting Research, Vol. 27, 1989, pp. 1-48.

Billett, M. T., Flannery, M. J., and Garfinkel, J. A., 'Frequent issuers' influence on long-run postissuance returns', Journal of Financial Economics, Vol. 99, 2011, pp. 349-64. 
Brav, A. and Heaton, J., 'Competing theories of financial anomalies', Review of Financial Studies, Vol. 15, 2002, pp. 475-506.

Brav, A., Geczy, C. and Gompers, P., 'Is the abnormal return following equity issuances anomalous?', Journal of Financial Economics, Vol. 56, 2000, pp. 209-49.

Brous, P., Datar, V. and Kini, O., 'Is the market optimistic about future earnings of seasoned equity offering firms?', Journal of Financial and Quantitative Analysis, Vol. 36, 2001, pp. 141-68.

Brown, P., Lee, M., Owen, S. and Walter, T., 'Corporate governance and the long-run performance of firms issuing seasoned equity: an Australian study', Working Paper (University of New South Wales, 2010).

Butler, A., Grullon, G. and Weston, J., 'Stock market liquidity and the cost of issuing equity', Journal of Financial and Quantitative Analysis, Vol. 40, 2005, pp. 331-48.

Cai, J. and Loughran, T., 'The performance of Japanese seasoned equity offerings, 1971-1992', PacificBasin Finance Journal, Vol. 6, 1998, pp. 395-425.

Carhart, M., 'On persistence in mutual fund performance', Journal of Finance, Vol. 52, 1997, pp. 57-82.

Carlson, M., Fisher, A. and Giammarino, R., 'Corporate investment and asset price dynamics: implications for SEO event studies and long-run performance', Journal of Finance, Vol. 61, 2006, pp. 1009-34.

Carpentier, C., L'Her, J. F. and Suret, J. M., 'Seasoned equity offerings by small and medium-sized enterprises', Working Paper (CIRANO Working Papers 2010s-07, 2010).

Chen, L., Novy-Marx, R. and Zhang, L., 'An alternative three-factor model', Working Paper (Washington University, 2010).

Cochrane, J., 'Production-based asset pricing and the link between stock returns and economic fluctuations', Journal of Finance, Vol. 46, 1991, pp. 209-37.

DeAngelo, H., DeAngelo, L. and Stulz, R. M., 'Seasoned equity offerings, market timing, and the corporate lifecycle', Journal of Financial Economics, Vol. 95, 2010, pp. 275-95.

DuCharme, L., Malatesta, P. and Sefcik, S., 'Earnings management, stock issues, and shareholder lawsuits', Journal of Financial Economics, Vol. 71, 2004, pp. 27-49.

Eckbo, E., Masulis, R. and Norli, Ø., 'Seasoned public offerings: resolution of the 'new issues puzzle', Journal of Financial Economics, Vol. 56, 2000, pp. 251-91.

Eckbo, E. and Norli, Ø., 'Liquidity risk, leverage and long-run IPO returns', Journal of Corporate Finance, Vol. 11, 2005, pp. 1-35.

Fama, E. and French, K., 'The cross-section of expected stock returns', Journal of Finance, Vol. 47, 1992, 427-65.

Fama, E. and French, K., 'Common risk factors in the returns on stocks and bonds', Journal of Financial Economics, Vol. 33, 1993, pp. 3-56.

Fama, E. and French, K., 'Multifactor explanations of asset pricing anomalies', Journal of Finance, Vol. 51, 1996, pp. 55-84.

Guo, L. and Mech, T., 'Conditional event studies, anticipation, and asymmetric information: the case of seasoned equity issues and pre-issue information releases', Journal of Empirical Finance, Vol. 7, 2000, pp. 351-77.

Harjat, M. and Garen, J., 'Why do IPO firms conduct primary seasoned equity offerings?', The Financial Review, Vol. 38, 2003, pp. 103-25.

Hasbrouck, J., 'Trading costs and returns for US equities: estimating effective costs from daily data', Journal of Finance, Vol. 64, 2009, pp. 1445-77.

Heckman, J., 'Sample selection as a specification error', Econometrica, Vol. 47, 1979, 153-61.

Huang, R. and Ritter, J., 'Testing theories of capital structure and estimating the speed of adjustment', Journal of Financial and Quantitative Analysis, Vol. 44, 2009, pp. 237-71.

Iqbal, A., Espenlaub, S., and Strong, N., 'Earnings management around UK open offers', European Journal of Finance, Vol. 15, 2009, pp. 29-51.

Jeanneret, P., 'Use of the proceeds and long-term performance of French SEO firms', European Financial Management, Vol. 11, 2005, pp. 99-122.

Jegadeesh, N., 'Long-term performance of seasoned equity offerings: benchmark errors and biases in expectations', Financial Management, Vol. 29, 2000, pp. 5-30. 
Jensen, M.C., 'Agency costs of free cash flow: Corporate finance and takeovers', American Economic Review, Vol. 76, 1986, pp. 323-29.

Korajczyk, R., Lucas, D. and McDonald, R., 'The effect of information releases on the pricing and timing of equity issues', Review of Financial Studies, Vol. 4, 1991, pp. 685-708.

Korajczyk, R., Lucas, D. and McDonald, R., 'Equity issues with time-varying asymmetric information', Journal of Financial and Quantitative Analysis, Vol. 27, 1992, pp. 397-417.

Larcker, D. and Rusticus, T., 'On the use of instrumental variables in accounting research' Journal of Accounting and Economics, Vol. 49, 2010, pp. 186-205.

Lesmond, D., Ogden, J. and Trzcinka, C., 'A new estimate of transaction costs', Review of Financial Studies, Vol. 12, 1999, pp. 1113-41.

Levis, M., 'Seasoned equity offerings and the short- and long-run performance of initial public offerings in the UK', European Financial Management, Vol. 1, 1995, pp. 125-46.

Li, K. and Prabhala, J., 'Self-selection models in corporate finance', in Eckbo E., ed., Handbook of Corporate Finance: Empirical Corporate Finance (Elsevier/North-Holland, 2008).

Li, E., Livdan, D. and Zhang, L., 'Anomalies', Review of Financial Studies, Vol. 22, 2009, pp. 4301-34.

Liu, W., 'A liquidity-augmented Capital Asset Pricing Model', Journal of Financial Economics, Vol. 82, 2006, pp. 631-71.

Liu, W., 'Liquidity risk and asset pricing: Evidence from daily data over 1926-2008', Working Paper (Nottingham University Business School, 2010).

Loughran, T. and Ritter, J., 'The new issues puzzle', Journal of Finance, Vol. 50, 1995, pp. 23-51.

Loughran, T. and Ritter, J., 'The operating performance of firms conducting seasoned equity offerings', Journal of Finance, Vol. 52, 1997, pp. 1823-50.

Loughran, T. and Ritter, J., 'Uniformly least powerful tests of market efficiency', Journal of Financial Economics, Vol. 55, 2000, pp. 361-89.

Lyandres, E., Sun, L. and Zhang, L., 'The new issues puzzle: testing the investment-based explanation', Review of Financial Studies, Vol. 21, 2008, pp. 2825-55.

Lyon, J., Barber, B. and Tsai, C., 'Improved methods for tests of long-run abnormal stock returns', Journal of Finance, Vol. 54, 1999, pp. 165-201.

Michaely, R., Thaler, R. and Womack, K., 'Price reactions to dividend initiations and omissions', Journal of Finance, Vol. 50, 1995, pp. 573-608.

Mitchell, M. and Stafford, E., 'Managerial decisions and long-term stock price performance', Journal of Business, Vol. 73, 2000, pp. 287-329.

Myers, S., 'Determinants of corporate borrowing', Journal of Financial Economics, Vol. 5, 1977, pp. $147-75$.

Myers, S. and Majluf, N., 'Corporate financing and investment decisions when firms have information that investors do not have', Journal of Financial Economics, Vol. 13, 1984, pp. 187-221.

Pastor-Llorca, M. and Martin-Ugedo, J., 'Long-run performance of Spanish seasoned equity issues with rights', International Review of Financial Analysis, Vol. 13, 2004, pp. 191-215.

Polk, C. and Sapienza, P., 'The stock market and corporate investment: a test of catering theory', Review of Financial Studies, Vol. 22, 2009, pp. 187-217.

Rangan, S., 'Earnings management and the performance of seasoned equity offerings', Journal of Financial Economics, Vol. 50, 1998, pp. 101-22.

Ritter, J., 'Investment banking and securities issuance', in Constantinides, G., Harris, M. and Stulz, R., eds., Handbook of the Economics of Finance (New York: North-Holland, 2003).

Schultz, P., 'Pseudo market timing and the long-run underperformance of IPOs', Journal of Finance, Vol. 58, 2003, pp. 483-517.

Shivakumar, L., 'Do firms mislead investors by overstating earnings before seasoned equity offerings?', Journal of Accounting and Economics, Vol. 29, 2000, pp. 339-71.

Shumway, T., 'The delisting bias in CRSP data', Journal of Finance, Vol. 52, 1997, pp. 327-40.

Shumway, T. and Warther, V., 'The delisting bias in CRSP's Nasdaq data and its implications for the size effect', Journal of Finance, Vol. 54, 1999, pp. 2361-89.

Spiess, K. and Affleck-Graves, J., 'Underperformance in long-run stock returns following seasoned equity offerings', Journal of Financial Economics, Vol. 38, 1995, pp. 243-68. 
Stehle, R., Ehrhardt, O. and Przyborowsky, R., 'Long-run stock performance of German initial public offerings and seasoned equity issues', European Financial Management, Vol. 6, 2000, pp. 173-96.

Stulz, R., 'Managerial discretion and optimal financing policies', Journal of Financial Economics, Vol. 26, 1990, pp. 3-27.

Subrahmanyam, A., 'Behavioural finance: a review and synthesis', European Financial Management, Vol. 14, 2007, pp. 12-29.

Teoh, S., Welch, I. and Wong, T., 'Earnings management and the underperformance of seasoned equity offerings', Journal of Financial Economics, Vol. 50, 1998, pp. 63-99.

Tobin, J., 'A general equilibrium approach to monetary theory', Journal of Money, Credit, and Banking, Vol. 1, 1969, pp. 15-29.

Womack, K., 'Do brokerage analysts' recommendations have investment value?', Journal of Finance, Vol. 51, 1996, pp. 137-67.

Xie, H., 'The mispricing of abnormal accruals', The Accounting Review, Vol. 76, 2001, pp. 357-73. 